\title{
On the Euphemistic Insinuation of the Historical Reality of America in the Poetic Historicity of I, Too, Sing America
}

\author{
Jun Luo ${ }^{1 *}$, Guicai Chen² \\ ${ }^{1}$ School of Foreign Languages, Zhaotong University, Zhaotong, China \\ ${ }^{2}$ School of Foreign Languages, Dianxi Normal University of Science and Technology, Lincang, China \\ Email: *531678237@qq.com
}

How to cite this paper: Luo, J., \& Chen, G. C. (2019). On the Euphemistic Insinuation of the Historical Reality of America in the Poetic Historicity of $I$, Too, Sing America. Advances in Literary Study, 7, 50-108. https://doi.org/10.4236/als.2019.72007

Received: March 8, 2019

Accepted: April 7, 2019

Published: April 10, 2019

Copyright () 2019 by author(s) and Scientific Research Publishing Inc. This work is licensed under the Creative Commons Attribution International License (CC BY 4.0).

http://creativecommons.org/licenses/by/4.0/ (c) (i) Open Access

\begin{abstract}
In the historical observation of Harlem Renaissance that has already been epitomized in the historical elaboration in the poetic production of Langston Hughes, what his readers have been insatiable with is that although both international and Chinese scholars and critics have not only made various valuable explorations of his poetic texts but also made a mention of the lower social position and their unfair treatment of the dark brothers in the American society dominated by whites' culture, they have hardly devoted their studies to this poetic text titled I, Too, Sing America to quest for the historical reality embedded euphemistically in the textual interweavement of this poetic text. Owing to their failure to do so in their studies, this paper will try to make an exploration of the euphemistic representation of the profound reality grounded on poetic historicity of this poetic text that dwells on historical reality of the miserable lots of those dark brothers.
\end{abstract}

\section{Keywords}

Historical Reality, Poetic Historicity, I, Too, Sing America

\section{The Analytical Inclinations of I, Too, Sing America}

To begin with the valuable exploration of the historical reality as has been carried in the analysis of this poetic text titled I, Too, Sing America, it is better to give an elaboration to the research background of this essay in a historical, social as well as cultural sense in association with the textual particularity of this poetic text in combination with its producer Langston Hughes who has been deemed as "Poet Laureate of the Negro Race" and an important figure for both the greater 
development and promotion of African-American cultures in terms of literature, music, theater, art, and politics through his sustainable and successive production of a variety of original poetic text in his poetic production over the Harlem Renaissance, or the Negro Renaissance in consistence with the New Negro Movement that has been generally considered as the first important movement of black artists and writers in the United States at that historical moment when they have to be faced with the historical, social and cultural barriers on their road to the pursuits of equal dignity and personality in the process of resisting against the identity crises imposed by the white citizens.

In this sense, this poetic text $I$, Too, Sing America, has carried the profound racialist meditations of this insightful African American poet on the unbearable, unforgettable as well as unbelievable discrimination and segregation of African-American folks, folklores as much as culture just as what he has written in line with what to be quoted below: "The very fact that Negroes do straighten their hair and try to forget their racial background and makes them different from white people..." (Singh, 1976). Given the historical dilemma in which African Americans have been lost in at that historical moment, it is quite necessary to find out the correspondent traces in American history that can be thought of as important echoes to the unintelligible and unimaginable bitterness of those African American, and make an illuminative exploration of the important suggestions this poet has proposed in his production of this poetic text for the very aim of inspiring his compatriots to strive and struggle for their own autonomous identification, optimization and eulogization. On the historical, social and cultural ground of what has been dealt with above, it can be seen in a clear fashion that the research aim of this essay to meet this academic needs of digging out the historical reality from the textual reality of this poetic text lies in the incontestable fact that this poet has a great impact on the historical evolution of African Americans, for he has turned out to be aware of the great importance of African-American culture as has been dealt with in the impressive lines of his poetic texts. In Turner's terms, this is in a position to be elaborated as quoted below "in many respects... there could be a literary culture among Blacks" (Turner, 1980). To a great extent, this poetic text has reminded the readers of this poet of not only the historical reality those dark brothers are forced to be faced with but also the independent identity, dignity and personality they are entitled to have because the historicity of this poetic text has too much to do with its textuality. In effect, it might be correlation between the poetic historicism of this poetic text and its poetic realism that best indicates the historical reality of that historical period in America that has been manifested in a euphemistic fashion.

Therefore, it is a great deal evident for the author of this essay to suppose that the theoretical insights of new historicism is likely to be applied in the theoretical and practical justification of the academic proposition of this essay that this profound historical reality of America in that historical period has been epito- 
mized in the construction of the poetic lines of this poetic text and the organic combination of some of those lines with others in a very ingenuous fashion because it is at least possible to find appropriateness for the research hypothesis of this essay as elaborated above in accordance with both the similar salient clarifications illuminated from the following quotation: "we younger Negro artist who create now intend to express our own individual dark-skinned selves without fear or shame... (Bone, 1998)". Similar with what has been voiced in the studies of this scholar, what is likely to be perceived from this poetic text is that this poet has kept it in his mind that the aim he produces this poetic text I, Too, Sing America is to express his own strong resistance against cultural racialism as has been mirrored in the historical progression of America in spite of his transforming the bitterness of Negros into humor and irony and the tolerable interpretation of the beauty of his dark brothers.

Grounded on the textual particularity of this poetic text, the correlation between the textual production of this poet and the historical progression of American society, as much as the historical illuminations acquirable from the perception and cognition of the historical implications implied in this poetic text, what can be explicitly seen from the academic proposition of this essay is that it is of research significance to deal with the historical reality of this poetic text in accordance with its textual historicity as to be expounded in the following two folds either in a theoretical sense or in a practical one.

In a theoretical sense, the systematic, successive and salient justification of the historical reality existing in the textual historicity of this poetic text in a succinct and coherent fashion is inclined to give rise to the theoretical reflection and meditation of literary theorists and literary historians who have insufficient or inadequate awareness of the dynamic correlation and interaction between the respective discourses between the theoretical rumination and clarification literary theory and literary history by means of reminding them of not turning a deaf ear to the important role literary manifestation especially poetic manifestation is likely to play in the enrichment of the historical implications of a given society and the revelation of the historical reality of it in the persistent pursuit of the historical and poetic truth in an euphemistic fashion.

It is this very reflection and meditation that help both those literary theorists and literary historians to bear in their minds in an explicit fashion that the truth to be dug out from the textual interpretation of poetic text is the sole truth to be told in a complicated society, for poets are much more ingenuous than historians in the articulation of both historical reality and historical truth as has been exemplified in the respective safety or security of the language forms, styles and diversities between poets and literary theorists and literary historians who have seldom told the truths of a given society in an apparent fashion even if they are not inconsistent with their instinctive conscience.

To be specific, the former are good at voicing the social reality, historical reality as well as psychological reality in an implicit fashion in spite of their being faced to receive the censorship of ideological, political, religious as well as moral 
correctness while the latter cannot but do so in an explicit fashion, which is apt to lead to the unnecessary problems in this censorship. For the sake of those unstoppable worries, those literary theorists and historians tend to conceal the truths interwoven in those social realities in order to meet the needs of political correctness at the cost of hiding the historical truth of a given society in the form of speaking for the rulers of that society regardless of the harm to swear the unforgivable vices of that society and prevent the development and promotion of the precious virtues of it.

Therefore, it is to this extent that the profound exploration of the historical reality of American society in view of the textual historicity of this poetic text is crucial for those literary theorists and literary historians to enable them to get across the very skills poets have been taking to give a presentation to the historical truths of a given society in an euphemistic way in the process of their poetic production, the academic and cultural values of the textual configurations of those poets, and then, to learn from those poets the poetic arts either available or unavailable in the artistic transmission of the historical and social truths of the society in which they have lived all their lives in an unnoticeable fashion.

With this artistic ingenuity kept in minds, it is quite possible for them to have a good understanding of the approach this poet has taken to show his profound concern for the miserable lives of those dark brothers in his insightful revelation and revaluation of the historical reality in which a series of unnoticeable truths have been buried, and to have a good knowledge of the textual reliability and validity of the truths told in this poetic text in addition to the strong sense of both the historical and social responsibility of this poet in combination with their honest retrospections of the harm they have been doing to the promotion of the society they have lived in and the language incompetence of them that leads to their failure to send their contributions to the universal transmission of those truths in their theoretical and historical texts.

However, what seems to be pitiful for those poets is that it is very difficult for the vast majority of their readers to have a very good understanding of those truths hidden in the ambiguous lines of their poetic texts, for most readers have turned out to be unable to acquire the exact implications of their poetic texts, the original intentions of their textual compositions, as well as their strong motivations of their ubiquitous populism in a profound fashion even if those readers are willing to take pains to shorten both the ideological and epistemological distance from those poets.

In most cases, what has been mentioned above is agnostic unless those readers are likely to share the same interest in poetic production, the same knowledge of poetic values, the same attitude towards the truths composed of both historical and social vices and virtues or in other words, both political and religious correctness and incorrectness, and the same populist or humanist stances in a very coincident fashion. In his sense, the historical and social truths interwoven in the textual textures of poetic text, is, to a great extent, agnostic because the textual encodement of those texts are unintelligible and the textual decodement of them 
tend to be impossible for the vast majority of poetic readers.

One important reason for the agnosticism of the truths carried in the articulation of those poetic texts is that those average readers of poetic texts are unmatchable with the professional readers of them in terms of their ideological and epistemological profundity. It is for this reason that the former tend to be regarded as mediocre readers and the latter are inclined to be respected as insightful readers. Since the vast majority of poetic readers are the former readers and the vast minority of them the latter, it is quite understandable that the truth is agnostic for the former and approachable for the latter. Therefore, what can be inferred herein is that poetic agnosticism is superficial phenomenon for the part of those mediocre poetic readers while poetic cognosciblism the truths for versatile and insightful readers who have access to poetic truths in a prophetic fashion.

In this case, the appropriate rehabilitation of the unknown truths of the historical reality concealed in the textual historicity of this poetic text is of great significance for both literary theorists and literary historians to familiarize themselves with or adapt themselves to the prophetic charms and values of this poet who has been free from the censorship of the political and racial correctness of his poetic text in a humorous and harmonious fashion after having a good understanding of the profound analysis of the prophetic language of this poet in his production of this poetic text.

Of course, it is also of greater importance for them to be aware of the important role poetic language has been playing in the outrageous revelation of the truths rulers are unwilling to share with all readers rather than speaking for those rulers via the application of sycophantic language as exemplified in this poetic text, and to have a very good knowledge of the unimaginable bitterness of the vast majority of the lesser beings just as what has been manifested in the innovative representation of the historical reality in this poetic text to show the profound compassion of this poet for the miserable existence and magnificent willingness of those African American dark brothers and his strong enthusiasm for and firm belief in the extensive transmission and promotion of the populist and humanist values of their African-American folk culture.

Moreover, the abundant illuminations those literary theorists and literary historians are likely to acquire from the historical analyses of this poetic text, are conducive for them to reflect the harm they have been done to the promotion of their theoretical populism and historical populism in a very ubiquitous fashion out of their instinctive goodness and conscience in the achievement of both their theoretical betterments and breakthroughs rather than their previous theoretical and historical fetishism as has been personified in the image of their rulers on account of their strong desire for their own promotion and safety in a sycophantic fashion.

In a practical sense, the historical interpretation of the truths buried in this poetic text in correspondence with or in response to the respective historical, social and cultural reality of American society at that historical moment according 
to correlation between the textual microcosm of this poetic text and the national macrocosm insinuated in the profound references of it is quite good for the current rulers and politicians of the countries around the world to take into account the universal values and contributions of their political populism, and for the vast majority of poetic readers to have a good access of poetic historicism of the poetic texts they have been reading and the poetic populism of correspondent poets.

As a matter of fact, the interpretation of this poetic text in this respect is also likely to set a good example for poetic readers to develop a very strong awareness of poetic populism, which has turned out to lay a sound foundation for the fulfillment of the humanist values of them, for they are supposed to bear in their minds in an explicit fashion that the highest values of their perceiving and cognizing poetic text lies in their original discoveries the good a poetic text might do to all dwellers of the world rather than their individual delights acquired from their aesthetic experiences of poetic appreciation.

In the minds of a variety of poetic critics, the attentions to be paid to the visible and virtuous interpretation of the invisible truths of this poetic text in consistence with the correspondent historical reality of American society in that historical context, is likely to throw insightful lights on the further development of the critical insights of them, for they are likely to acquire either critical illuminations or insufficiencies from the specific logical justification of the academic proposition of this essay and turn those illuminations or limitations into new starting points of the enrichment and betterment of their new critical insights.

For the part of the dedicated poetic lecturers in the field of poetic education, their effective and extensive transmission of the historical truths to be rediscovered in the profound elaboration and revelation of the implicit truths veiled in the shadowy darkness of the superficial phenomenon of certain unreliable reports or records is a good inspiration for the learners they have been devoted their efforts to throughout their lives, for they have been setting a good example for those learners on account of their firm and indomitable persistence in the transmission and pursuits of truths from the historical reality based on what has been exemplified in both the ingenuous insinuation and appropriate suggestion of this poetic text.

With what has been clarified above taken into account, what is likely to be made apparent in the research aim, research background, research hypothesis and research significance of this study is that the implementation of this academic exploration is of very great importance in more than one respect, for it is conducive for the readers of this poetic text and this essay to get close to the truths blurred in the inappropriate distortion of the superficial impression that has been given to historical events related to the racial discrimination those dark brothers have been suffering from in their lives on a daily basis as has been manifested in the textual production of this poetic text in line with the historical reality carried in the textual historicity of this poetic text, and crucial for the policy makers of a good many countries to highlight their historical awareness in seek 
for truths from the very truths interwoven in the textual historicity of poetic texts in an unnoticeable fashion, and indispensible for the citizens of those countries to make it believable that the very truths of historical reality are inclined to be reduced to or condensed in the textual textures of poetic texts.

\section{The Critical Insufficiencies on I, Too, Sing America}

For a long time after the publication, this poetic text I, Too, Sing America has been paid either appropriate or inappropriate despite inadequate critical attentions in the insightful and profound critical analyses of and critical reviews on various issues as what has been reflected in this poetic text among both international poetic critics and Chinese poetic critics from their respective perspectives, for they have been, in some measures, discussing not only much about the indispensable role the poet of this very poetic text has been playing, in a successive fashion, in promoting the international rumination and transmission of the critical illuminations of the implications and impacts of this poetic text and other poetic texts produced by this poet on the basis of the comparative analyses they have been making of those poetic texts even though they have just made an insufficient mention of what has been entailed in this poetic text in a historical sense in the light of the lower social positions of those dark brothers and their unfair treatment as dealt with in this poetic texts in reference to the social reality, cultural reality as much as historical reality of American society in that historical period owing to hegemonic cultural domination of the advantageous culture of the whites in overall combination of the poetic texts of this poet with his perception of the unbearable experience of those dark brothers. This can be made to be apparent from the following reviews of the international critical analyses and Chinese critical elaborations of respective issues of this poetic text although they haven't grounded their studies of the historical reality of this poetic text in details according to its respective textual historicity as to be touched upon in the following four respects.

Firstly, the critical attentions paid to this poetic text are available in correspondent analyses of foreign poetic critics. In the case of both the critical explorations and elaborations of those foreign poetic critics with regards to the correspondent issues mirrored in this poetic text, most of them has given an account of the poetic styles of this poet based on some of his poetic text from different perspectives and their innovative findings have inspired a great many scholars even if few of them have either made a direct mention of this poetic text, or focused their studies on the historic reality of the sound bitterness those dark brothers have suffered from their own lives in accordance with the textual historicity of this poetic text.

For the sake of the correspondent authority, typicality and objectivity of the critical analyses available in foreign poetic criticism, this paper cannot but make a relevant review of the insightful views carried out in the academic studies of foreign poetic critics but considering the limited content to be carried in this research and the critical and analytical relevance to this research, what to be sum- 
marized below will be just the respective studies of three foreign poetic critics (Rampersad, Brooks and Hitchens) to share with the vast majority of readers of this poetic text and those of this essay their insightful comments, arguments and conclusions of their studies, and find out the academic potentialities left in their studies that are likely to provide the tenable space for this essay.

In the close observation of the studies of the first foreign critic, it has been found that as Rampersad mentions this poem in his studies directly, so his studies center on the discussion of the Writer's descriptive styles in I, Too, Sing America and the closely-knit combination of his poetic texts with his own personal experience and the valuable relevance to the life of Black people. In a sense, his study as has been indicated in The Life of Langston Hughes, Volume I, 1902-1941 has mentioned that: "I, Too, Sing America is a sympathetic, yet clear-eyed portrait of one of America's most controversial writers that also manages to be a sweeping depiction of the black experience in this country and abroad during the first four decades of the $20^{\text {th }}$ century (Rampersad, 1986)". What is worth much more academic admiration in this meaningful and meticulous study is that Rampersad does not shy away from "the ambiguities and ironies in Hughes's life: his possible homosexuality... (Rampersad, 1986)". Considering this, what can be seen from his analysis of this poetic text and the life of this poet is that Rampersad's study has taken into considerations both the pros and cons of the life of this poet in a respective fashion and given a clear picture of both his academic satiations and dissatisfactions with his poetic text.

In association with the academic views voiced in the studies of the second foreign poetic critics, what has been made evident in his critical views is that unlike the studies of Rampersad, Brooks has come up with his opposite views on the strong worries of this poet about the quality of his poetic text. To clarify this point, he argues that this poet has given his response to his personal encounter with racism rather than his sorrows about his own sincere devotion to his poetic craft in view of his great eager to polish it. In his terms, "Hughes is simply not very vulnerable... (Brooks, 1986)". In addition, Brooks's study has also given a presentation to his readers the sound concern of this poet for the miserable lives of African Americans in order to show his intolerance to see the poor situation of his dark brothers who have lived in America on a daily basis as he has claims like this "America never was America to me... (Brooks, 1986)".

In terms of the critical insights of the third foreign poetic critic, what is worth mentioning in this critical review is that similar to the situation of that in this poetic text, it has been figured out in the studies of Hitchens in a definite fashion that this poet has spent a lot of his time in the schools and classes of the whites, and has little choice but to put up with in a brave fashion when he has to be faced with vulgar abuses and discrimination of those whites after an extensive and intensive reading of many poetic texts of this poet. In this study, this foreign poetic critic has learned from Rampersad that this poet has given a distinctive impression on the minds of his readers with his work titled Good bye Christ and Good Morning Revolution, as well as his plays on the Scottboro case and other 
outrages of racialism. To find sufficient evidences in this respect, he has come to his mind correspondent critical comments made by Rampersad the pressures of this poet as to be quoted below "On each of the few occasions in his (Hughes's) life when his internal pressures proved too great to bear, the cause would be private rather than racial (Hitchens, 1987)". In spite of the great efforts he has made in this respect, Hitchens still finds that there is no sufficient evidence that can be used to indicate that color plays decisive role in the acquisition of the happiness of this poet and help him to get rid of his unhappiness in an effective fashion.

Based on the analysis mentioned above, it can be seen in an explicit fashion in the international review of the academic explorations of foreign poetic critics that they center on in their praiseworthy studies the rich and complicated life experience of this poet characterized with the ebbs and flows of his life he has been suffering from in his communication with the white and the blacks, his innovative poetic styles as has been shown in the analyses of his other poetic texts, and the unbearable discrimination he has recounted in his poetic texts. But they have neither made a study of nor made no mention of this poetic text in detail, not to speak of giving an interpretation to this poetic text $I$, Too, Sing America with regard to its historic reality grounded on its textuality in association with the historical truths that have been embedded in the actual experience as has been epitomized in the communication between those fellow dark brothers cherished by this poet in this poetic texts out of his racial hospitality, and their counterparts owing to his implicit racial hostility because although few essays have mentioned this same poetic title I, Too, Sing America, what has been touched upon in the specific analyses and elaborations of those essays has nothing to do with what has been highlighted in the textual production of this poetic in a very remarkable fashion. Therefore, in a strict sense, those essays are not supposed to be considered as the analytical clarifications or explorations of this poetic text owing to its irrelevance with the analytical insights to be dwelled on in accordance with the poetic particularity of this poetic text.

Secondly, in comparison with the critical attentions that have been paid to this poetic text, Chinese poetic critics have turned out to make much more adequate study of it in more than one respect to enrich the critical observation and examination of this poetic text, for a good many of those poetic critics have devoted more of the textual spaces of their academic essays to either the explications or analyses of other poetic texts of this poet like Not Without Laughter (1930), Negro speaks of Rivers (1921), The Weary Blues (1926), and Fine Clothes to the Jew (1927) in terms of their image, symbolic implications, estrangements as well as their responses to American Dream respectively from different perspectives but fewer to this poetic text I, Too, Sing America. By and large, they have, to some extent, given certain interpretations of the poetic features, images and symbolic implications of those poetic texts but none to the historical reality of America as grounded in the textual historicity of this poetic text. To make a general review of the academic achievements of Chinese poetic critics in this respect, the following five representative studies will be picked out 
to show the current status quos of the academic explorations of this poetic text in accordance with the critical insights of correspondent Chinese poetic critics. Considering the typicality of those studies and their academic relevance to the academic topic to be explored in this academic essay, the typical findings of the following five Chinese poetic critics (Liang-gong Luo, Li-hua Liu, and Wen Liu) ought to be reviewed to critical traces of this poet and this poetic text of him in the following five respects.

The first Chinese poetic critic who has made an exploration of the humorous poetic language of the poetic texts of this poet, is named Liang-gong Luo, for he has focused his study on a detailed and penetrative analysis of the creative conceptions and arts of this poetic text to emphasize the endless efforts and explorations that this poet has made throughout his life so as to demonstrate and interpret his humor in his poetic production. In the words of this Chinese poetic critic, this reflects two strategies the Negroes have taken in their lives as to be dealt with below respectively: the strategy they take to lead a better life and that they take to prevent the whites from destroying the eternal and internal environment that is subservient to their development.

The analytical focus of his studies relies on the interpretation of the humor of this poet in reference to what has been embedded in his poetic texts. On the mind of this poetic critic, this humor is inclined to be considered as the core value of both the exclusive psychological mechanism and cultural tradition of those dark brothers as mentioned in this poetic text that they have been drawing on from their experience along American continent. In terms of the cultural significance implied in the humor of the poetic texts of this poet, what has crossed the insightful minds of this poetic critics is that the humor of this poet, on the one hand, acts as an important bond that links the unbendable fortitude in fighting against the dominant culture of the whites to reach his fond dream of seeking for the democracy, liberty, dignity and identity those dark brothers ought to be entitled to have in their lives, and both strategic choices he has made are, to a great extent, very conducive for him to convey his democratic conception and supposed to be treated as an important approach for him to convey his firm faith in humanity; on the other hand, this humor is in a position to be thought of as a crucial element to have a good understanding of the literary texts produced by this poet (Luo, 2005).

The second Chinese poetic critic who has dwelled on the poetic virtuosity of this poet and that epitomized in his poetic texts in relation to his empirical perception in his poetic production is Li-hua Liu. In her comparative analysis between the poetic production of this poet and the empirical accumulation of him, the studies of this poetic critic Li-hua Liu has touched the profound similarities and differences between the poetic texts of this poet and his individual experience in an explicit fashion.

In the logical justification of the major academic proposition of her essay, she has attached greater importance on the implications of the poetic texts of this poet like Dream, Dream Deferred as well as Dream Variation that have been 
sharing a great relevance with one another in terms with his pursuits of American Dream because she has made a lot of valuable explorations of the unbearable discrimination those dark brothers have suffered with respect for both their self-consciousness and their great expectation of true democracy and liberty according the abundant inspiration he has already given to those American African dark brothers (Liu, 2000). To this extent, she has also has touched upon in her academic study the cultural value of the American African culture that has bodied forth the cultural and spiritual pursuits of American African dark brothers.

The third Chinese poetic critic to make a study of the poetic texts in this respect is Wen Liu. In a relative sense, the academic clarifications of the American African culture in the academic explorations of Wen Liu are a great deal different from those of the former two domestic scholars, for he has focused his studies on the great influence this great poet Langston Hughes has instilled into his poetic production in combination with the illumination he has acquired from his appreciation and perception of both blues and Jazz music based on the spiritual interactions between those popular music of American African dark brothers and the ideological and epistemological promotion of him exemplified in the textual construction of his poetic texts, which is especially true of his meticulous exploration of the strong melancholy that has been characterized with the articulation and representation of the thematic concerns of the songs that have turned out to be rooted in elaboration and expectation of American Dream even though it is impossible to be realized in correspondent cultural reality of American society because those dark brothers have been suffering from the harsh discrimination of their white brothers. In this case, the great expectation of their rosy future has turned out to fall though in spite of their firm beliefs in their ability to turn their tears into smiles.

In terms of this Chinese poetic critic, the American Dream epitomized in the poetic texts of this American African poet Langston Hughes is not only a disappointment at the racial cruelty of American social reality, but also the harmonious potentiality of a beautiful expectation of a American society that has been filled with liberty, equality and fraternity and devoid of ruthless racial discriminations (Liu, 2007).

In a word, he has made a valuable exploration of both the potential expectation of and suggestion for the ideological and epistemological liberation of those miserable dark brothers who have been leading a very miserable life. It is the perception and cognition of this implication of his poetic texts that Martin Luther King finds out the inspiration to make his famous speech under the title of I Have a Dream to inspire those dark brothers to struggle for the protection of their legal rights.

The fourth Chinese poetic critic to make a study of the poetic texts in this respect is Yi Zheng who ought to be considered as the epitome of a group of typical Chinese poetic critics, for she has shared with them a very conspicuous academic inclination to make a very general mention of the poetic texts of this poet 
in one of her academic essays rather than make a profound exploration of the insightful implications of one of the poetic text produced by this poet in one of her academic essays.

An example in this regard can be found in her analyses of a number of the poetic texts of this poet from the prospective of postcolonialism in such an over-general fashion that the post-coloniality implied in those poetic texts have been elaborated in a profound fashion to make it evident that the post-coloniality of those poetic texts she has mentioned in her essay is bound to leave an unforgettable impression on the readers of her essays owing to her failure to make an analysis of each of those poetic texts in an overall fashion (Zheng, 2008).

In short, what is supposed to occur to the minds of the academic readers of those poetic critics clearly and respectively as has been exemplified by both the analytical succinctness and textual extensiveness of this poetic critic is inclined to be that their analyses of the correspondent poetic texts seem to be to brief to provide their readers with a critical insight in an profound fashion, for what their readers are in bad need of in the specific understanding of those critical views tends to be the profundity of their critical acumens and foresights manifested in their respective analysis of each of those poetic texts they have picked out to be the analytical samples for the logical and thematic justification of their correspondent academic propositions.

The fifth Chinese poetic critic to make an analysis of the poetic texts in this respect has a great deal to do with the two critical essays of two Chinese poetic critics namely Jun Luo and Gui-jun Li and those two academic essays have been respectively titled Study on the Negroes Cultural Otherness in I, Too, Sing America and A Culturalist Interpretation of the Dark Brothers' Sound Bitterness in Hughes's I, Too, Sing America. In a similar sense, those two essays have been devoted to the justification of their respective academic propositions in a respective fashion for the aim of figuring out the social causes for both the miserable and intolerable experiences of those dark brothers from different perspectives as to be reviewed in the following two folds.

In the first place, the former essay has dealt with the cultural otherness of the dark brothers in American society as has been mirrored in this poetic text in terms of the cultural otherness between the Negroes' uniqueness and the whites' sameness, the cultural otherness between the Negroes' oneness and the whites' wholeness, as well as, the cultural otherness between the Negroes' unselfness and the whites' selfness (Luo, 2018).

In the second place, the latter essay has touched upon the dark brothers' sound bitterness in accordance with what has been manifested in this poetic text with regards to the dark brothers' sound bitterness in the cultural tolerance of their unbearable treatments suffering from their cultural counterparts, the dark brothers' sound bitterness in the cultural resistance against their cultural counterparts' deeply-rooted bias, the dark brothers' sound bitterness in the establishment of their own cultural liberty and independence, as much as the dark brothers' sound bitterness in their contribution to the cultural prosperity of 
American culture to show adequate concern for the dilemmas and improvements of the miserable lots of those dark brothers (Li \& Luo, 2018).

To sum up, Chinese poetic critics have made a specific study of the language styles of this poetic text, the relevance of the poetic texts of this poet to American Dream, as much as the harsh lives of the discriminated dark brothers in American society at that time, and some of them have devoted the textual spaces of one of their academic essays to the analysis and elaboration of a given academic proposition of their essay on the foundation of their adequate understanding of this poetic text.

However, it is a little pitiful that none of them have given an interpretation of the historical reality of American society in accordance with the textual historicity of this poetic text just as what has been grounded on the textual microcosm exemplified in the historical and social representation of this poetic text in an Euphemistic fashion by means of taking into account the coincident or at least the consistent historical echoes between the historicity of this poetic text and the textuality of the historical truth of American society as revitalized in this poetic text and the historical awareness of this poet in his production of this poetic text.

Thirdly, as has been indicated in the brief review that has been made above, the critical studies of this poetic text in the critical analyses of both foreign and Chinese critics tends to be chiefly characterized with two following distinctive inclinations. One is involved in the general ruminations of or summarizations of the mechanical generality of the language forms and thematic implications of the poetic texts of this poet in a superficial fashion, with no profound meditation on a single poetic text of this poet in an entire essay, let alone a great emphasis placed on this poetic text I, Too, Sing America. The other refers to the academic phenomenon that a special analysis of this poetic text in an entire essay but it has little to do with the ruthless revolution of the historical reality of American society as has been manifested in the textual historicity of this poetic text in combination with the indispensable role of this poet and this poetic text in promoting it on the basis of digging out from the historical awareness and the historical implications of this poetic text the very historical truths that the social lives of those dark brothers have been characterized with their lower social positions and unfair treatments in the gradual evolutions of American society and history on account of the historical domination of the whites in the development of American society just as what has been indicated in the careful combination of his poetic production with the factual description of the unbearable experience of those dark brothers.

Fourthly, for the sake of the academic inadequateness in the explorations of critical insights of this poetic text in the academic clarifications of both foreign and Chinese poetic critics, this paper will try to give an interpretation of the historical reality of American society in a profound fashion in consistence with the textual historicity and the historical textuality of this poetic text to rehabilitate or revitalize the historical reality of American society that has been reflected in the 
historical bitterness of those dark brothers as has been indicated in this poetic text in an explicit fashion.

\section{The Analytical Devices for I, Too, Sing America}

To clarify the reasonable theoretical supports for both the logical references and practical justifications of the academic proposition of this essay, it is better to give an account of the theoretical evidences to be applied in the textual analyses of this essay in general sense to pave way for the following interpretation of the historical reality of American society on the basis of the textual historicity of this poetic text in the logic justification of this essay in line with the theoretical insights that have been proposed in the elaborations of the historical reality to highlight the historical essence of this poetic text in a theoretical fashion.

The reason for the choice of this literary theory is primarily based on the correlative interactions between the historical evolution of a given society and the revelation of its historical truths through the voluminous penetrations of the historical realities into the textual production of literary texts in an implicit and ingenuous fashion so as to highlight the historical awareness of literary authors and their historical missions to infuse into their texts the authentic reality of a given historical moment in a given society as far as they are able to blur the ideological and epistemological censorship of the ruling groups of that given society to check its political correctness, religious correctness, moral correctness as well as cultural correctness. In this respect, historical researchers and even archeologists are unable to match or at least keep in pace with literary writers, especially poets because they are less skilled than poets in the subtle application of language either in a poetic fashion or in an artistic fashion to hide the semantic profundity of their texts into the superficiality of them so that even the majority of inexperienced readers have least difficulty in having a good understanding of their intentions but have most difficulty in figuring out the exact implications of the poetic texts of insightful and intelligent poets. In essence, even if those readers are experienced political readers, they are also unable to make an exact explanation to the hidden implications of those poetic texts, let alone the truths buried in them just as what has been dwelled on as below in the theoretical elaboration of the historicity of text and the textuality of the history.

To be put in the words of Louis Montrose, the exploration of the historical reality of American society at that historical period in the lights that have been thrown in the theoretical clarifications of new historicism in accordance with the textual historicity of this poetic text I, Too, Sing America, is in consistence with the theoretical concern of new historicists in terms with the historicity of literary texts and the textuality of the history of a given society in a reciprocal fashion.

In line with what has been mapped out in insightful academic account of Louis Montrose as to be quoted below in the elaboration of the correlative interaction between historical recounts and literary texts, the former refers to such a view that "history is conceived not to be a set of fixed, objective facts but, like the 
literature with which it interacts, a text which itself needs to be interpreted" (Abrams, 2010) while the latter that any text is in a position to be regarded as a discourse consisting of representations including verbal formations like "ideological products, or cultural products of the historical conditions specific to an era" (Abrams, 2010).

Even though it has been claimed in the theoretical elaborations of a good many other historicists, those cultural and ideological representations in literary texts are confined to the production, confirmation and propagation of the perplexed power structure of a dominant or subordinate society in an helpless fashion, it ought to be kept in the minds of poetic readers that even if literary texts like novelistic texts, dramatic texts and essayistic texts are unable to be free to tell historical truths in an explicit fashion, it is possible for them to be embedded with those truths in an implicit fashion and despite their failure to do so, it has no impact on the factual and actual revelation and transmission of the stoppable or unstoppable truths in the textual production of poetic texts in such an implicit fashion that the vast majority of poetic readers are unable to be aware of, let alone figure them out on account of the rare wisdom that has been shaped or epitomized in the extraordinary virtuosity of them in the ingenuous poetic manifestation in the course of the textual production of their poetic texts.

Grounded on the analytical feasibility as has been mapped out above, it can be made evident in an explicit fashion that it is of great theoretical appropriateness to make a profound analysis of the historical reality of American society in that specific historical period in accordance with the poetic historicity of this poetic text I, Too, Sing America by means of connecting it with the particular historical context of it, for it is likely to help the readers of this poetic text to have an authentic understanding of the truths that have been epitomized in the textual interweavements of this poetic text with the help of its unrepeatable historicity that has been loaded with the unbearable or intolerable bitterness of the African American dark brothers as has been mentioned in this poetic text I, Too, Sing America.

With the correlation between historical evolution and poetic production taken into account, it is high time to give an interpretation of the historical reality of American society with the help of the poetic historicity of this poetic text in an overall fashion to highlight the historical values of poetic texts and the historical missions of poets who ought to pay a special attention to the actual existence of human beings rather than turn a deaf ear to it owing to the poetic populism embraced in their poetic souls rather than keep in both utilitarian and timid pace with the politicians of their time in a blind fashion driven by their poetic officialism or bureaucraticism.

\section{The Euphemistic Insinuation of the Profound Historical Reality of America in the Poetic Historicity of I, Too, Sing America}

On the whole, the theoretical and practical justification of the academic proposi- 
tion of this essay is inclined to be composed of the poetic historicity of this poetic text $I$, Too, Sing America in the euphemistic exemplification of the genuine historical reality of America at that historical moment, the historical poeticity of this poetic text in the factual revelation of the historical reality of American society in that historical period, as well as the correspondent strategies taken to represent the historical reality in the textual production of this poetic text for the aim of telling the moset implicit truths of the reality of American society in the least explicit fashion just as what to be analyzed in the following three respects based on the analytical combination of the textual samples of this poetic text with the theoretical insights of both the textual historicity and the historical textuality of a given literary text as proposed in the theoretical ruminations of this new historicist Louis Montrose.

\subsection{The Poetic Historicity of I, Too, Sing America in the Euphemistic Representation of the Historical Reality of American Society}

Having a historical reading this poetic text $I$, Too, Sing America in an ingenuous fashion, it is possible to refresh the historical memories of the dark brothers as has been mentioned in the poetic lines of this poetic text and revitalize the historical realities in consistence with the poetic historicity of it owing to its historical traces that have been left in the textual construction of this poetic text to give a clear picture of the true historical situations those dark brothers have lived in and make it clear that the interaction between this poetic text and the historical context it has been produced is likely to help its readers to make their ways to the correspondent rediscoveries of the historical truths just as what has been suggested in the studies of the vast majority of new historicists that a given literary text is in a position to be placed in its relevant historical context to help its readers to have a better understanding of the specific historical conditions of the particular era in which it is produced.

It is, in this sense, that this poetic text I, Too, Sing America has much to do with the slow growth of the historical evolutions of those dark brothers from their ignorant acceptance and blind tolerance of the racial oppression, discrimination, deprivation or exploitation to their intentional opposition to those whites on account of their spiritual retrospection in an autonomous fashion in order to subvert the social and cultural realities that have been characterized with the miserable marginalization, isolation and segregation they have been suffering from in their experiences as a result of the domination of the whites who have been exaggerating their cultural and social values at the cost of dwarfing those of those dark brothers just as what to be made evident in overall justification of the first minor academic proposition of this essay that has been dealt with afore.

According to the structural configuration of the logical justification of the first minor academic proposition of this essay that it is feasible to put into the analyt- 
ical application of this poetic text the theoretical insights of textual historicity in the rehabilitation of the historical truths of American society according to social, cultural and historical reality exemplified ingenuously in this poetic text, the historical exploration of the poetic implications with respect for the historical truths implied in this poetic text is supposed to be composed of the naked realities in the light of the racial oppression of the dark brothers in American society, the racial discrimination of them, the utmost deprivation of their rights, the futile opposition of them to their unfair treatments, as well as expectation of them despite of the unbearable situations and dilemma they have been lost in the following five folds.

In the first place, what has been characterized most in the textual production of this poetic text is its historical representation of the racial oppression of dark brothers in their repetitive contacts with the whites who have isolated those dark brothers from their sights to protect their own social and cultural identities and dignities regardless of the harm they have been doing to the possible destruction of the social and cultural identities and dignities because of their habitual oppression of those dark brothers who have been considered to be inferior to them on their basis of their so-called social and cultural superiorities to their counterparts who cannot but submit their barbarous actions in an unconditional fashion owing to the social and cultural domination they have been entitled in that society because of their submission to the ruling class of that society according to what to be touched upon below in analytical elaborations of the textual samples of this poetic text and the historical truths over there.

For one thing, the miserable situation of those dark brothers can be traced back to the historical delineation of the social and cultural oppression of them in American society at that historical moment. As a matter of fact, it is in this very hard situation that this poet Langston Hughes has made his great effort to associate the history of African American with his production of this poetic text $I$, Too, Sing America, to voice their unbearable bitterness and share it with the readers of this poetic text to speak for the various dark brothers of African Americans just as what has been shown in the last three lines of the second stanza of this poetic text.

Just as what has been evidently mirrored in the disgraceful experience of this dark brother in the second stanza of this poetic text as mentioned above, what can be felt in acute fashion in the vivid poetic delineation of the social unbalance between the whites and this dark brother is that he has become a disadvantageous or an underdog of American society in presence of those hegemonic whites in consistence with the unbalanced juxtaposition between "they" and "I". In a historical sense, this juxtaposed unbalance is adequate for the voluminous appearance of the barbarous oppression of one party of this historical context to the other of it in addition to the additional and effective participation of "company" which is likely to worsen to the extreme the very balance that ought to be maintained between them, for the social inequality will be bound to be characterized with the remarkable deviation to the weak one owing to the strong beliefs 
of the strong in their superiorities to their counterparts. It is this sense of social and cultural superiorities that enable the strong to take a very good advantage of their hegemonic rights to highlight their social and cultural identity and dignity regardless of the repression of the inborn social and cultural identity and dignity of the weak in the form of the social and cultural humiliation that have been rooted in the darkness of the skin of this dark brother.

To this extent, it can be understood in a clear fashion that the darkness of his skin has led to the oppression of his social and cultural positions owing to the violent banishments of the whites who have held that the sights of their guests at this dark brother at their homes, will be bound to give rise to the strong social and cultural condescension, discrimination and even humiliation in spite of their bad need of their honest services to provide them with good convenience in a ambivalent fashion. In a social sense, this elegant isolation of this dark brother by sending him to eat in the kitchen in a violent fashion, has most to do with the unanimous consistence of the collective hostility of the whites against the dark brother in a morbid fashion and the exclusive and egoistic awareness of those whites who have been playing a dominant in the decision of the social and cultural communication of American society at that historical moment, for the entrance to the kitchen has, in some measures, bodied forth a kind of spiritual banishments and isolation if not social and cultural exclusion.

In the sense of historical morality, the society of America at that time is inclined to be marked with the racial morbidity of the whites who have a tight control over the development and promotion of social and cultural communication in an inter-racial fashion owing to their biased social and cultural superiorities to this dark brother who ought to have been entitled to communicate with them in a decent fashion but actually not as has been typified in his submissive responses to the violent isolation of the whites like what has been indicated in the last three lines of the second stanza of this poetic text.

Based on what has been reflected in the lines referred to above, it can be made in a conspicuous fashion that the social and cultural inequality of the whites just as what has been sufficiently externalized in their hegemonic domination in American society in that historical period, has engendered the social and cultural injustice of the whole social and cultural context because they have built their violent dominations on the unconditional submissions of this dark brother who has been peopled with endless angers but are unable to let go of them in an equal fashion. In this case, what he cannot but do is to swallow his anger and stand their barbarity in a reluctant fashion to adapt him to this morbid social reality that has been characterized with its social ills out of optimistic tolerance for the aim of seeking for the sustainable accumulation of his physical strengths and the sound foundation to be laid for his resistance against those civilized barbarians and cultured savages in the future.

For another thing, this social and cultural isolationism and barbarianism as has been demonstrated in an implicit fashion the social and cultural representation of this poetic text is likely to be in consistent with the social and cultural 
echoes and feedbacks of, and responses to the illuminative academic findings in the fields of the successive cultural explorations, interpretations as well as elaborations of a variety of social scholars who have been paying a special attention to the social and cultural inequality that results in the cruel reality of American society and the harsh repression of a good many African Americans in the gradual and successive evolution of American history over that historical period in accordance with what has been demonstrated in the following two cases.

The first case in coincidence with what has been unveiled in this poetic text is that the demographical unbalance between disadvantageous African Americans and the advantageous whites is so conspicuous that it has come to the minds of the readers of this poetic text the demographical record that in line with the historical record of American population, although the remarkable population of African Americans with a population of over 25.2 million that has made up $11.7 \%$ of the whole American population, has become the largest proportion of the racial and ethnic minority in America, this demographical gap has thrown them into the terrible danger or even crisis of their living a miserable life in a very miserable situations on account of the cruel oppression of the whites (Zhu, 1991).

What is even worse, it can be seen in the numerical evidence offered above that this demographical unbalance is doomed to become the social and cultural inequality of American society in that the dominant whites are prior to take charge of the optimized social, cultural and educational resources that their counterparts ought to have made use of, which makes this worse unbalance a worst one in a vicious circulation because the white will be richer and their counterparts poorer owing to the implicit expansion of the gap between the resources that are available for them to dispose of or take advantage of to continue their respective existences in that society.

The second case in coincidence with extensive employments and enslavements of African Americans at the homes of the whites and the barbarian translation of them into the servants or slaves of those whites in a dehumanized fashion just as what has been revealed in the poetic lines quoted above from the second stanza of this poetic text, has become a very popular social and cultural phenomenon of the American society at that time in accordance with the historical records of in the staggering transformation of American society to the effect that few decades after the first blacks have been brought to north America in 1619 , the increasing demands for cheap labor has led to a massive deterioration of the slave trades among the whites in American society at that time.

In the words of this poet, those dark brothers have been bought and sold at that time to white traders like cattle at auctions in a free and legal fashion because of their failure to dispose of their lives and fates and their inability to prevent their social and cultural identity and dignity in that historical context that has put them into the danger of being bought, sold and transferred to one another among their white masters who have been in bad need of making them serve as 
their "agricultural labors or domestic servant" (Zhu, 1991) at the cost of their unimaginable disgraces and even humiliations in spite of their reluctant indignation to swallow their furies in that their miserable living situations have dwarfed them and made them condescended in the social cruelties of American society in that historical period regardless of both the physical and spiritual imprisonment, enslavement, as much as torture in addition to the potential ideological and mental distortion, stupefaction as well as alienation as epitomized in their thorough acceptance of all impersonal oppression and persecution and their timidity to resist against this social and cultural inhumanity, for they have been instilled into their minds the total submission or subjugation to their masters that have been playing a very important role in both the ideological and epistemological manipulation of them by means of preventing them from being able to achieve their own ideological and epistemological independence and liberty as a result of their own timid and helpless unwillingness, inability as well as failure to resist against both the ideological and epistemological stupefaction and imprisonment they have been forced to suffer from their masters in view of the submissive responses the dark brother has given to his master in the form of laughing and eating over there in an abnormal satiation with this discriminative humiliation as he has been told to when he is asked to eat in the kitchen in an obedient fashion.

Having taken into consideration the social and cultural consistence between the poetic reality of this poetic text and the social reality reflected in the social studies reviewed above, it ought to cross the minds of the readers of this poetic text that the poet of this poetic text has implanted into the ingenuous textual textures of the textual construction of his poetic text the cynical indignation in the superficial presentation he has given to the cruel truths buried in both the social reality and historical reality of American society at that time that have been masked with the superficial social and cultural tolerance he has woven in the poetic lines of this poetic text. What has been impressed in this consistence is that it has turned out to be evident and true that the textual historicity of this poetic text has left a remarkable imprint on the overall and profound revelation of the historical reality of American society in that historical context according to what has been mirrored in the historical microcosm of this poetic text in the light of the violent fact that the correlative interaction between the dark brother characterized in this poetic text and his masters and their accomplices is inclined to give the readers of this poetic text a deep impression that the helpless of the subjugation of the dark brother has most to do with the inhuman manipulation and domination of their masters. In other words, this poet has given a picture of his poetic pessimism or even his poetic cynicism in the name of poetic patriotism or poetic optimism to maximize the spiritual stupidity of this dark brother.

To sum up, in line with the analytical elaboration offered above, it is not coincident but inevitable that the demographical unbalance, unevenness and the asymmetricality between the dark brother characterized in this poetic text and 
his white masters and their accomplices are bound to give rise to the social and cultural inequality and the correspondent social and cultural injustices triggered by this very inequality that has turned out to be an important reason for this dark brother to be forced to be subjugated to the oppression of his white master, and the asymmetrical and uneven consistence between what has been reflected in the textual samples of this poetic text and what has been demonstrated in those analytical samples of the social studies mentioned above, tends to be an important sigh for the clarification of both the theoretical and practical feasibility that the poetic historicity entailed in this poetic text has been playing an important role in telling the historical truth rooted in the social and cultural phenomenon which unveils the historical reality of American society at that historical moment to the effect that the dark brothers in that historical context of American society have been repressed by their masters in a ruthless fashion in conjunction with the noticeable popularity of slave trade in that time.

Considering the logical feasibility in both theoretical and practical sense that has been ruminated above in view of the correlative interaction between the textual historicity of this poetic text and the historical reality carried over there, it is quite appropriate and reasonable to tell that the implication of this poetic text $I$, Too, Sing America has unfolded the profound truths buried in the historical events of American society because the manipulation and isolation the dark brother has been suffering in his life has been telling the very truth that the African Americans have been repressed by their masters owing to their failure to resist against the hegemonic discrimination and segregation of their masters who have been intending to have a good control over the minds and thoughts of their dark servants or slaves in line with the oppressive imprisonment and enslavement of those white masters in addition to the poetic truth that in the sense of the theoretical insights of new historicism, it would be impossible for the vast majority of readers to have a true understanding of the historical reality epitomized in the dominant repression of the whites if there are no literary texts because the nonliterary texts like historical texts are unlikely to tell the historical truths of a given society by means of unveiling its social and cultural reality on account of its failure to hide the truths it ought to tell in the ambiguous and implicit fashion that can be used to prevent the vast majority of readers from having a good perception and recognition of the historical reality of that society grounded on their acute and foresighted awareness to take correspondent countermeasures to cope with the ideological and epistemological disturbance and manipulation of the authorities.

In the second place, in reference to the theoretical inspiration of new historicism, it ought to be seen from the poetic revelation of the historical truths implied in the implicit textual implications of this poetic text I, Too, Sing America, that have been closely concerned with the discriminative reality of the racial hostility of the whites in the mainstream awareness of American society that has been rooted in the ideological and epistemological representation of the whites who 
have taken from their racial preconception that they are superior to their dark servants or their dark slaves driven by the popular permeation into the minds of their servants or slaves their racial contempt for and prejudice against those servants or slaves to reach the aim of putting them into their domestic or private prisoners via both the social and cultural violence that have been frequently used to have a very tight control over the ideological and epistemological births or deaths of those miserable prisoners in accordance with the correspondent justification of this historical representation in the following two folds.

On the one hand, the discriminative reality of the historical truth of this poetic text is also in a position to be figured out or found out in the elaboration of the remarkable effects the ideological and epistemological stupefaction of the whites have on the physical and spiritual domestication of the dark brother depicted in this poetic text as has been typically exemplified in both his autonomous submission to his masters and positive subjection to his inferiority to those masters who have been interested in or good at showing their servants or slaves their superficial superiorities just as what has been admitted in the first three lines taken from the second stanza of this poetic text.

In conjunction with what has been indicated in those lines, what seem to impress the readers of this poetic text most is that the discriminative inclination embodied in the racial delineation of this dark brother and the intentional distinction of him in line with his darkness and his unimportance has made it clear that in the poetic delineation of the historical bitterness of African Americans, both the physical and spiritual discrimination of them has become a key word that has been used to make the textual configuration of this poetic text in tune with the popular isolation of those African Americans from their masters to reveal the discriminative truths that have been buried in superficial concealments of the historical reality in the plausible explanation to the correlation between the dark brothers and their white masters in American society at that historical moment on the foundation of the very great efforts the latter have been making to manipulate the ideological and epistemological promotion of the former in their daily lives and prevent them from having a good understanding of the historical truths blurred in the harsh historical reality they have to be faced with in an invisible fashion, for it is the treacherous approach the latter often take to prevent the spiritual retrospection of the former.

In the case of the satirical revelation of the historical reality of American society at that time in the form of giving an account of the racial discrimination in detail that has been based on both the physical and spiritual discrimination articulated in the textual production of those lines for the aim of showing the discriminative indignation of his poet with his readers and the passionate compassion for the unbelievable bitterness of this dark brother, he has chosen to weaken his discriminative anger at or hatred for the most unforgivable humiliation those white masters have been imposing upon this dark brother in an acceptable and appropriate fashion to hide his strong objection to and passionate resistance against the purposeful concealments of the historical truths of American society 
in the name of showing his patriotic satiation with the miserable or tragic experiences of this dark brother in this poetic text who, in essence, ought to be considered to be the archetypes of the African Americans in American society to strengthen his poetic indignation at those inhuman white masters in the form of weakening it in a superficial phenomenon of the textual configuration of those lines to lighten the racial sensitivity of the whites and tightening the unspeakable cruelty of this discriminative reality that has been paralyzing the instinctive freedom of speeches of this dark brother who cannot but irritate in his mind but dare not tell the truths woven in historical lies and superficial phenomenon in the implausible transfiguration or transplantation of the ambiguous truths into unreliable lies in a subtle fashion, for he has given his readers an acceptable impression that this dark brother has been satiated with the racial violence of their white masters who have been best at forcing their servants or slaves to be submissive to their domestic violence as epitomized in the application of the transitive verb "send" in an imperative fashion at the cost of robbing him of his instinctive racial identity and dignity.

To this extent, what ought to be kept in the minds of the readers of those three poetic lines is that the poet has unveiled the veiled truths of American society in that historical context in the light of the historical reality that has been decorated in the historical interweavement of the discriminative reality of that society for the satiation of the white masters of this dark brother in the shape of achieving their satisfaction with their dogmatic manipulation of their servants or slaves via both their social and cultural mesmerism and narcissism, which is conducive for the poet to get far away from the social and cultural skepticism of the whites who have been dominant in the poetic censorship of poetic publications in the name of the plausible escapism in his poetic production.

Of course, those who are able to do so in that social and cultural atmospheres characterized with meticulous examination are supposed to be regarded as either poetic heroes or poetic warriors who have let go of their indignant satires in the form of superficial subjugation in such an ingenuous fashion that the vast majority of poetic readers around the world are unable to find out the true poetic intention they have buried in their poetic texts in the form of the optimistic transplantation of the tragic discrimination into the comic presentation to the pessimistic worries, for this poetic art has, to some extent, bodied forth the rare critical wisdom that has been concealed in their poetic production that has been achieved in the form of poetic witticism or optimism to cover the actual criticism or pessimism of them, in lieu of the rare poetic versatility as has been shown in the poetic texts of most mediocre poets in an explicit fashion because they have been succeeding in making their true emotional certainty manifested in an uncertain fashion so that the vast majority of poetic readers are unable to have an exact understanding of what has been voiced in their poetic texts. To make it easier, they have been skilled at call the names of the white masters of African Americans in the plausible praises for them either in such an uncertain or inscrutable fashion that those white masters and even the poetic readers of 
their poetic texts are unable to figure it out.

In the minds of most poetic readers, it is very difficult for them to have a very good knowledge of the thematic certainty, ideological certainty, epistemological certainty, emotional certainty, stylish certainty and referential certainty of those poetic texts because all of them have been visualized in an opposite fashion. Therefore, it is in this sense that everything poeticized in those artistic delineations is inclined to be agnostic for the parts of the vast majority of those poetic readers because of their failure to make their ways to the efficient exploration of the social, cultural as well as historical motivations of those homo sapiens who have been dedicated to and professionalized in the field of poetic production in the most optimized fashion just as what has been done in the textual production of the poetic text that has been chosen to be the analytical samples of this essay for the evident and appropriate justification of the academic proposition proposed in this essay.

On the other hand, compared with the invisible revelation of the discriminative reality of African American dark brothers in American society, it is quite easy for most cautious readers to have a good understanding of the historical representation of this discriminative truths in the rehabilitation of the historical reality of this society in a visible fashion as long as they are willing enough to give an insightful and overall observation, reflection as well as examination to the correspondent findings of social studies, cultural studies as well as historical studies that have been aimed to give an account of the physical and spiritual discriminations those African Americans have been suffering from in the discriminative realities they have to be faced with and submitted to throughout their lives for their sustainable and successive existence in that historical contexts just as what has been suggested in the following case study.

What has turned out to be quite similar to the discriminative reality as has been reflected in textual world of this poetic text, is that both the physical and spiritual discrimination of has also given rise to the close attention that has been paid to social analysis of the historical reality in accordance with what has been epitomized in the social phenomenon with regards to the historical reality of American society at that historical moment. This is available in the historical analysis of a Chinese cultural study aimed to work out both the physical and spiritual discrimination of the African Americans in terms of the color of their skin that has been endowed with them upon their births, and, both the social and cultural inferiority of them in the unbelievable prejudices of their whites masters that have been believed not to be entirely confined to their previous racial inferiority to their correspondent masters in reference to correspondent and cautious examinations and reexaminations of certain important historical events in that historical context, for they have also been looked down upon in that society in view of their responsible inferiority, habitual inferiority, honest inferiority, behavioral inferiority, cooperative inferiority, disciplinary inferiority, ethical inferiority, ancestral inferiority, intelligent inferiority, educational inferiority, ideological inferiority and epistemological inferiority. It is those biased inferiori- 
ties that make those African Americans very unequal with their masters just as what has been dealt with in this study that those African Americans has been "assiduously propagated as a justification for their continued subjugation" (Zhu, 1991) in their lives, for their docile obedience, submission and subjugation to the hegemonic and unreasonable demands, orders and requirements of their white masters have been accepted an stereotyped standard to be used to have an important assessment of their would-be superiority that has to be achieved at the cost of the losses of their equality, liberty, identity as well as dignity. Otherwise, they are inclined to be faced with the high risks of being treated to be inferior to their dominant masters because in the recount and review of the historical realities of American history, it is possible to turned out to be that those African Americans have been conceived to be scary in repetitive fashion due to their unique skin color just as the discriminative attitudes that have been held towards the color of the skin of Othello that has been considered to be a scaring color, a mark of danger, and a symbol of eternal other in accordance with what has been pictured in the racial stereotypes of the historical realities embedded in Shakespearian play Othello.

In comparison with what has been demonstrated in this poetic text in an implicit fashion and this historical analysis in an explicit fashion, what is supposed to cross the minds of the readers of this poetic text is that the amazing similarity between the historical realities revealed in those two cases, is that the poetic lines quoted above from this poetic text has, to a great extent, unveiled the profound social and cultural truths of the historical realities of American society in that historical period in an most invisible fashion that has turned out to be conducive for this poet to get free from the disturbances, accusations and even persecutions of the authorities, to give a very clear picture of the physical and spiritual discriminations African Americans have suffered from in their lives on account of both the greedy hegemony and barbarity of their white masters, and let go of the most furious indignation of his bosom in the sense of cynical realism coated in the form of admirable patriotism.

To be brief, what needs to be aware of from those analyses in line with both the theoretical edifications and illuminations of new historicism, is that the way that has been dealt with above and taken by insightful poets to represent and rearticulate the historical realities of a given society just as what has been done in this poetic text in the revelation of the historical truths of that society, has been inclined to be effective for poets to voice their authentic views and avoid the hegemonic preventions of the authorities but likely to give rise to the worries that the historical realities of that society might tend to be unknown to the majority of poetic readers on account of their inability and failure to have a good understanding of the social and cultural truths buried in those poetic texts in addition to the purposeful and preventive concealments of the authorities owing to the avoidance of the harm the revelation of those truths are likely to do to their manipulation of those who have been entitled to have a tight control over the thoughts of the ruled. 
In those two cases, the truths of a given society are likely to be agnostic or made unknown to all, for it is possible for them to be buried in the textual ingenuities of those poetic texts owing to the difficulty or impossibility for the readers to have an overall perception and cognition of them, and hidden in the intentional concealments of the authorities as a result of either their reluctance or unwillingness to release the truths that are harmful to the manifestations of either their unforgivable or inexcusable faults and dispositions.

In this sense, what is in a position to be fortunate is that the unbelievable similarity between the historical reality entailed in this poetic text in an ambiguous fashion and that reflected in case study mentioned above, has made an exception to show that the profound historical truth of a given society like American society in a given historical time is likely to unveiled in a given poetic text that has been produced at the same historical moment in the same society in an ingenuous fashion to reach the aim of putting a stop to the academic thoughts of historical skepticism, historical nihilism, as much as historical agnosticism as long as the poet of that poetic text is intelligent and insightful to reduce to an approachable extent the distance between the foresights of that poet and the perception of his readers in the subtle and unmatchable application of the poetic insinuation into the historical truths of both the social and cultural realities of a given society at a given time as what has been epitomized in the effective combination of the organic textual components of his poetic text with the unaffected permeation of that truth into the textual construction of that poetic text.

In the third place, what ought to be emphasized on the poetic revelation of the historical reality of the American society in that historical text in view of what has been voiced in this poetic text, is closely concerned with the illuminations that are available over there to help its readers to have a good understanding of the financial deprivation, liberal deprivation, cultural deprivation as well as educational privation in the American society that has been popularly dominated and manipulated by the white masters of African Americans according to the four types of deprivations to be elaborated below one after another.

The first deprivation to be dealt with in the following justification is the financial deprivation the African Americans have been suffering from and putting up with in their lives owing to the national legalization and popularization of slavery and slave trade throughout southern America where African Americans are entitled to be bought and sold at will to serve as the servants or slaves of the whites before the abolitionist movement because in combination with the historical context of this poetic text, it can be inferred from the six lines of the second stanza of this poetic text that the dark brother characterized in this poetic text has been bodying forth the dark brothers who have been sharing with him the same miserable experiences. In this sense, it can be put in an honest fashion that this dark brother is a typical archetype of a large number of dark brothers who have been forced to do all manual jobs their white masters are unwilling to free of charge, to eat the leftovers those masters are reluctant to tastes, and have their meals in an unnoticeable place to avoid the social disgraces of their mas- 
ters.

In response to what has been exemplified in the historical reality revealed in a monograph dealing with the slave trade of Black Texans, it is reasonable and legal for slaver traders to bring the servants or slaves they have to the slave markets like Galveston, Houston and many others and sell them to factory plantation, farm owners, or urban citizens just as what happen to the cattle of numerous farmers at the prices from 300 to 2000 dollars in accordance with their age, sex and ability to undertake manual work and make profits for their masters (Barr, 1996), for the very aim of paying off their debts regardless of the separation of those slaves from their parents, brothers and sisters.

In this case, something that seems to worsen the lives of those servants or slaves is that all the profits those servants or slaves have made have nothing to do with themselves because they are rarely or less paid by their white masters for what they have been doing. In a modern sense, this can be regarded as the earliest boom of the economic deprivation in America in pace with the development of bourgeoisie over there owing to the increasing migrations from European countries where industrial revolution has been promoting the economic expansion to meet the tremendous needs of accumulating original capitals to quicken the economic development of bourgeois society and the role those servants or slaves have been playing in American society, is akin to what the proletariats have been playing in European societies.

In short, the historical reality in the clear revelation of the profound economic truth in correspondence to the financial deprivation pictured in the poetic insinuation of this poetic text, is surprisingly similar to what has been indicated in the case that has been elaborated above just as the very financial deprivation those dark brothers or African Americans have been suffering from in their lives owing to the constructive or stereotyped inferiority that has been entitling their white masters to legalize or rationalize their deprivation of the profits they have made for those masters who have been believed to be superior to either those dark brothers or African Americans who have been bought or sold as servants or slaves in that historical contexts that have been associated with the historical realities of American society in that historical period.

The second deprivation to be touched upon in the organic justification to be given below, has most to do with the liberal deprivation those dark brothers or African Americans have been tolerating in their lives just as what has been manifested in the second line of the second stanza of this poetic text.

Grounded on what has been reflected above in this poetic line, it can be perceived in an explicit fashion from the discriminative experience of this dark brother that the correlative interaction between him and his master in presence of the guests who have dropped in a visit to this master has seemed to make it clear and evident that this white master has been dominating the lives of this dark brother in a barbarous fashion, for he has been depriving this dark brother of his liberty in social communication or the basic rights to take part in social communications by virtue of making the fullest use of the hegemonic superiority 
he has been considered to be to this dark brother in reducing to the least the very communicative liberty of this dark brother. In this way, the poet has implanted into the textual production of this poetic text the implicit revelation of the hidden historical truths in the cruel deprivation of the basic rights of liberty of this dark brother in consistence with the social reality of America at that historical moment.

In fact, this social phenomenon in regard to the domination of the whites and their crazy deprivation of the dark brothers or African Americans in the form of preventing them from the legal pursuit of their basic civil rights in liberty has long been noticed and emphasized in the Declaration of Independence that has made the point of the rights for all Americans to seek for their liberty, equality and happiness.

However, it is not the case in reality. In accordance with the historical records of America, the vast majority of those dark brothers or African Americans are unable to be entitled to carry out their basic rights concerning their liberty that has composed of their liberty to decide their presence of or absence from the togetherness of their white masters in lieu of being deprived of their masters their innate liberty to do so, their liberty to make their own speeches or deliver their own discourses to voice their needs, their liberty to protect their own security from being violated and their liberty to pursue their own happiness.

This is the historical truth at that time that has been coincided with what has been mirrored in this poetic text. From the point of view of the theoretical implications of new historicism, the textualization of this poetic text, is, to a great extent, the historicization of the important historical events, the profound historical truths as well as the authentic social phenomenon of American society in a most implicit fashion at that historical moment in terms of the rigid confinement of the rights of liberty that dark brothers or African Americans ought to have had in bettering their lives and enhancing their index of happiness.

The third deprivation to be dwelled upon in the following justification of this essay is inclined to be closely connected with the blurred representation of the ruthless cultural deprivation the dark brothers or African Americans have suffered from the cultural repression of their white masters just as what has been shown in the second poetic line taken from the second stanza of this poetic text. In some measures, the textual contextualization of this poetic line has stood for the cultural victimization of the historical victims of the barbarian cultural deprivation of those dark brothers or African Americans in American society in that historical situation just as who has been bossed to eat in the kitchen owing to their hegemonic deprivation of the cultural identity and dignity of this dark brother who has been made to be characterized with cultural illiteracy on account of both the cultural segregation and stupefaction of his white master at random that have been believed to be significant for the cultural confinements of this dark brother to prevent him from his sensitive awareness of the importance for him to seek for his ideological and epistemological resistance against his master at the risk of destroying his habitual submission to every harm his master 
has been doing to him.

As recorded in American history, what has been figured out in the analysis of this poetic text, the cultural glorification and valuation of the whites in American society at that time has turned out to be based on the cultural deglorification and devaluation of their servants or slaves because it has been recorded in American history that a good number of states have tended to legalize in a cultural sense to segregate those dark brothers or African Americans from their cultural interactions with the dominant cultural masters by means of depriving them of their legal rights to receive education, to take shelters, and go to the restaurants and other cultural facilities specialized in the good treatment of the whites, sending them to do the lowest paid job, and keeping them from the performance of their cultural rights and duties before the passage of the laws that have been laid down for the emancipation of slaves by Abraham Lincoln 1863 ranging from the gradual legislation of the Thirteenth Amendment to that of the Constitution in 1865.

In association with what has been resembled between what has been historicized and textualized in this poetic text and what has been recorded in American society at that time, what is supposed to be generalized in an explicit fashion from the analyses that have been made above to unfold the historical ambiguity that has been preventing the historical truth concerning the historical realities of the cultural deprivation of the dark brothers or African Americans from being told, is that this poetic text has been playing an important role in the overall manifestation and articulation of this social and cultural reality in American society at that historical moment in an ingenuous and unintelligible way so that the vast majority of readers of this poetic text are unable to figure out the profound connotations implied in it save a very literal understanding of it from various perspectives owing to their inability, timidity and unwillingness to dig out the historical truths buried in this poetic text.

The fourth deprivation to be touched upon in the logical elaboration to be given below is closely related to the unimaginable educational deprivation the dark brothers or African Americans have been suffering from in their everyday lives just as what has been exemplified in this poetic text based on what to be justified in the following two folds.

On the one hand, it has been reflected in the first three lines of the second stanza of this poetic text that the lives of the dark brother poeticized in the composition of those poetic lines have been saturated with a series of unfair phenomenon that has been characterized with the educational deprivations, for those hegemonic and barbarian deprivations have been serving as important approaches to the revelation of the slave trade in that historical context.

It is the historical legality of buying and selling slaves in a free fashion that makes the miserable lives of a large number of dark brothers and African Americans just as what has been mirrored in the sound bitterness rooted in the tragic experiences of this dark brother characterized in this poetic text and what has happened to cattle on the cattle market, for it can be inferred from the historical 
context of this poetic text that this dark brother is at least a servant if not a slave who has been bought to work for his white master. And the work he has undertaken has robbed him of the possibility to receive primary education for the gradual growth of his intelligence, let alone well-qualified education that can be received for the quick growth of his intelligence that enables him to be capable to compete with his master and other white masters.

Therefore, what has hidden behind those poetic lines is a historical truth that the free and lawful slave trade popularized in that historical context that allows dark brothers or African Americans to be bought and employed as the servants or slaves of the whites, has actually deprived them of the important opportunity they ought to take to receive a primary education, and the helpless absence from this education is the major reason for them to be ignorant and submissive when they have to be faced with the ruthless repressions and deprivations. To put into the shoes of those white masters, what has happened to their servants or slaves is just what they have expected most.

To this extent, what has been blurred in those poetic lines is an unbalanced, unfair and unreasonable exploitation of the basic rights that those miserable dark brothers or African Americans are in a position to have to receive well-qualified education and then change their lives. The legalization of this educational exploitation is inclined to be considered as the right reason for the deterioration of the racial communication of American society and the asymmetrical development of American education at that historical moment because this unreasonable legalization is inevitable to give rise to the strong racial conflicts between African Americans and their white masters, to shake the social stability of American society and prevent the remarkable progress and development that ought to be made in that historical context. In fact, what the poet wants to voice in those lines is that it is the high time for the dark brothers to batter this educational bond epitomized in the form of educational deprivations and foster the development of American education.

On the other hand, what has been voiced in those poetic lines of this poetic text has been, historically, and affectionately echoed both in the important explorations and reflections of or meditations on the educational deprivations in American society. In other words, those poetic lines of this poetic text have given a correspondent response to the bitter experiences of African Americans as what has been reflected in the important historical records of American history because of the impossibility for them to make an educational negotiation with their white masters who have been trying every means to promote the educational stupefaction of their servants or slaves and prevent them from being aware of the educational importance for their intellectual and intelligent growth for the sustainable maintenance of their dominant position in the full application of the good educational resources that have been possessed by them all the time.

What is inclined to give a deep impression on the minds of most readers, is, that a number of black Americans like John Brown have broken through this 
educational deprivation and fully aware of the very great importance for them to resist against the educational deprivation of the whites as has been seen in the abolitionist movement, to inspire those dark brothers or African Americans to fight against the educational hegemony and monopoly of the whites, and perform their basic rights to receive good education in American society.

In fact, this has been serving as an important impetus for the back leaders like Dr. Martin Luther King Jr. to promote the remarkable progress of American civil rights movement and realize that the miserable treatments those dark brothers have been suffering from in their passive and disgraceful social and cultural communication with their white masters is utterly contrary to the holy creed of liberty, equality as well as fraternity in accordance with what has been proposed in civil rights movement and the protection of human rights and human dignity and it is this educational deprivation that prevents them from acquiring a remarkable intellectual, intelligent, ideological as much as epistemological development.

Based on what has been illuminated from those analyses, it can be summarized in a clear fashion that, in view of the theoretical insights of new historicism, those poetic lines of this poetic text as have been mentioned above, have turned out to bear the evident witness to reveal the historical truth of American society at that historical moment in line with educational deprivations the dark brothers have to be faced with and aware of as a result of the educational hegemony and monopoly of their white masters in their ambiguous suggestion of the harm those masters have been doing to them and the strong accusation against them voiced in an euphemistic fashion in combination with what has been conveyed in the last three poetic lines of the second stanza of this poetic text.

In essence, it has been pictured in an invisible fashion in the visual imagination and association of those lines that the educational tolerance of those dark brothers in terms of the educational deprivations they have to bear has been run out and gotten so close to their breaking points that a strong need to struggle against and resist against both the educational domination and manipulation of their master in the form of a social reform is on the increase, for this is the very solution they are able to work out to subvert the cruel educational reality at that historical moment in the entire process of unveiling the correspondent educational truths to be told over that time.

In the fourth place, as is in a position to be kept on the correspondent revelation of the historical reality of the American society in that historical text in combination with what has been ingenuously echoed in this poetic text, the dark brother visualized in the pictorial depiction has been forced to make up his mind to make him grow up and keep fit to replace his master and resist the violent repression of his master in an oppositional fashion in the form of the identity construction, identity substitution and dignity protection of the dark brother in a subversive way as has been epitomized in this poetic text because of the gradual birth and growth of his independent awareness, liberal awareness, equal awareness, protective awareness, and oppositional awareness to be elaborated in the 
following three respects in a respective fashion in accordance with what has been articulated in the last three lines and the five lines of the third stanza of this poetic text.

The first opposition to the white master of this dark brother as has been exemplified in the ideological birth and growth of this dark brother in this poetic text, the construction of the racial and cultural identity of the dark brother has been pictured in the last three lines of the second stanza of this poetic text.

The racial and cultural humiliation tasted in the first three lines of this poetic text has occurred to the mind of readers the insatiable or even indignant traces of this dark brother who has been historically considered to be inferior to his white master and the friends of this master in more than one fold. In a normal sense, he ought to be angry with them in an abnormal fashion but he has chosen to be considered to be abnormal to swallow his anger in friendly fashion when he has to be faced with this sound bitterness by turning it into sweet bitterness or bitter sweetness, with neither traces of sadness nor those of happiness imprinted on his silent and smart face that has been loaded with unusual serenity and gentility.

In most cases, his responses are likely to be interpreted in two folds in a disputable fashion. For one thing, the tolerable attitudes he has held towards or the forgivable responses he has given to the hegemonic violence of his white master just as what has been undergrounded in his reluctant laughter at the discriminative demands of this master, have, in some measures, stood for his temporary inferiority to his aggressive white master who have a very good control over him on account of his timidity to irritate his master, for he has to rely on this master to accumulate his physical and spiritual growth and weaken his strong dependence on his master by means of getting rid of the risks to be starved to death. For another thing, his generous responses to his master are inclined to be thought of as an unmatchable literacy that has conspicuously bodied forth his profound manifestation of both his own intellectual and cultural retrospection and pacification grounded on his firm pursuits or fond dreams of both inter-racial friendliness and togetherness for the aim of both the salient and sustainable progress and prosperity of American society at that time.

From this point of view, neither of the subversive motivation blurred in the former view in regards to the foresighted wisdom implied in this laughter nor the literacy ruminated in the latter one, have been made aware of in the repetitive exploration of the profound connotations of the sophisticated laughter felt in the dark brother in this poetic text in response to the unbearable rudeness of his master based on the witty tranquilization of his indignation and the intelligent transformation of it into his unnoticeable preparation for his subversive and substitutive opposition to his master as a result of his awareness of the historical essence or truth that the perspicacious and profound superiority of an underdog performed in the form of perspicuous and perceivable inferiority in a given society at a given historical moment is much more powerful and insightful than the implicit inferiority of a lucky dog unnoticed in his aggressive superiori- 
ty.

Therefore, it can be seen from the semantic interweavement of those two opposite views that have been unable to come to the minds of most readers of this poetic text that the poet bases the construction of the racial and cultural identity of the dark brother on to awaken his fellow dark brothers to take correspondent measures to strengthen themselves, to improve their social and cultural positions, and construct their racial and cultural identity and dignity to show their hospitable hostility for their master under the veil of hostile hospitality, with the invisible racial brilliance harbored in both their superficial racial tolerance of the domestic violence of their white masters and profound opposition to that of them on their way to the exploration of the opportunities that will be available for them to let go of their racial and cultural oppositions in the form of both their construction and consolidation of their racial and cultural identity and dignity in a quantitative fashion for the aim of outdoing their white masters in more than one respect in an implicit fashion.

The second opposition to the white master of this dark brother is embodied in both the ambiguous and ambivalent articulation of the strong motivation he has hidden in his mind to distract the close observation and examination of his master in order to enable him to make it come true that his strong opposition to the racial and cultural domination of this master as can be seen in this poetic text is likely to be realized in the form of the substitution of the cultural identity and dignity of his master in the future in accordance with the profound intention that has been woven in second line of the third stanza of this poetic text.

That is because the poet of this poetic text has been aware that it is his racial and cultural mission and responsibility to enable his dark brothers to be determined to make themselves grow strong enough to protect them from being oppressed, discriminated and segregated by their masters by developing their racial and cultural confidence in strengthening their bodies and minds on their clear awareness of the power and wisdom of themselves, to make them able to stand the test of the most challenges they have to take in the exploration of the way to get rid of both the demonic and ruthless oppression of their white masters in the form of autonomous opposition to it, to help them protect themselves against the barbarian and brutal deprivation of their inborn rights and liberty in an oppositional fashion, and above all, make it possible that they are able to take place of their white masters in terms of the domination of both the racial and cultural identity and dignity for the achievement of their own racial and cultural usurpation in the future in the presence of the hegemonic domination of their white masters.

In a way, what has been mirrored in this line of this stanza of this poetic text seems to represent the vivid historical image between those dark brothers and their white masters in the protection of their own racial and cultural identity and dignity from being deprived by their white masters in an oppressive way and the replacement of their previous identities as servants or slaves with future masters of their white masters in a substitutive fashion for the aim of highlighting both 
their racial and cultural centrality, and weakening, confining or dismantling those of their white masters on the way to the legalization and centralization of their own rights to be endowed with racial and cultural equality, liberty as well as fraternity just as what has been demonstrated in the great changes that have taken place on the way to the historical refreshment and betterment of those dark brothers, for the sound and similar historical evidences are likely to out to be available in the oppositional activities of those progressive and perspicacious African American organizations like the National Association for the Advancement of Colored people.

In a historical sense, the members of those organizations have presented petitions and made negotiations for both the extensive and remarkable improvements of the economic and social status of their fellow dark brothers by taking their cultural, intellectual and legal arms to challenge the oppressive reliability and validity of their white masters who have been entitled to give a dominant and demolished treatment of their servants or slaves in the form of the physical and spiritual enslavement, imprisonment as well as stupefaction of those servants or slaves to prevent the increasing development of the racial and cultural prides of them in an intentional fashion.

In short, what appears to be fortunate enough is that they have turned out to be smart enough to keep in their minds that they are supposed to hide their own racial, cultural and intellectual superiority in the correspondent inferiority of them in the form of their racial, cultural as well as intellectual simplicity, superficiality and generality to avoid the attentions of their masters owing to their profound understanding of the truth that the formlessness of their superiority in those folds are the best way for them to hide it in the conspicuous forms of their inferiority to their masters in those correspondent regards in order to achieve their final aim of racial, cultural and intellectual opposition to those of their masters just as what has been indicated in the second line of the second stanza of this poetic text in consistence with the ideological and epistemological enhancement, and the sound consolidation of the resistant willingness of the dark brother.

In the fifth place, with respect to the gradual revelation of the historical reality of American society in the historical context of the textual production of this poetic text, both the great and glorious expectation of the dark brother in this poetic text has been believed to derive from the unbearable exploitation of their white masters in the crucial repression of their racial, cultural as well as social individuality and particularity in their correspondent pursuits of their own racial dignity, cultural liberty and social equality just as what to be ruminated in the following three respects.

The first expectation of this dark brother in this poetic text is inclined to be epitomized in the gradual reconstruction of their own racial dignity of the majority of African Americans after the entire destruction that has been seen in the racial discrimination and segregation of their white masters just as what has been implicitly echoed in the subtle revelation of the genuine historical reality of 
American society in the textual production of this poetic text in consistence with the blurred textual historicity of this poetic text that is supposed to indicate the profound understanding of the historical truths of that historical period.

The historical correspondences with or responses to the historical reality can be found in the second line of the third stanza of this poetic text, for it has seemed to remind the dark brothers of the dark brother poeticized and historicized in this poetic text that they ought not to count on nobody but themselves to rehabilitate the racial dignity they have been endowed with upon their growth, and enable, entitle, or empower them to make the best of their own superiority to win the fondest respect of their white masters rather than their incurable and futile dependence on the compassion of those masters.

In this sense, the dark brother in this poetic text is in a position to be considered as the personification of the poet who has been serving as one of the greatest the spiritual leaders of Harlem Renaissance for all African Americans and playing an extremely important role in inspiring their fellow dark brothers to pick up all their courage and make the best use of their wisdom to protect their racial dignity and prevent it from the vicious destruction of their counterparts by quickening the awakening awareness of the majority of those dark brothers and making it the indispensable backbone of both their physical and spiritual retrospection and liberation in the pursuits of racial rehabilitation in association with what has been woven and embedded in this line "Pll be at the table" (Rampersad, 2001).

In an ontological sense, this is an articulation of the determination this poet has expected his fellow dark brothers to make to resist against their white brothers and subvert the inferior positions of their being stereotyped as either the servants or slaves who have been imprisoned, stupefied and enslaved all the more on the basis of their epistemological growths to the effect that they have been aware that they are not born to be inferior to their masters but made to be that owing to their inadequate effort to highlight their superiority and that no one is born to be superior to the rest and all of them ought to make great efforts to strengthen themselves.

According to what has been manifested in this line, in addition to having a good taste of the found sweetness acquired from the sincere respect of their masters and getting rid of the sound bitterness they have been suffering from those masters for a long time, they ought to be delighted to protect against the casual destruction or deprivation of their masters their racial identity and dignity that have been rooted in both the racial pride in and the racial confidence available in their own resolutions to subvert their masters.

Grounded on the analyses made of above, it can be concluded that the historical reality of American society at that historical moment in terms of the reconstruction of racial dignity of African Americans has been consistent with what has been ingenuously historicized in the textual revelation of the third stanza of this poetic text, for it has been recorded in American history that after the dedicated to the close correlation between Dr. Martin Luther King Jr., and the civil 
rights movement (Emblem Jr., 2013) for the liberation of African American citizens, the American congress at that time has enacted a brand new civil rights bill to liberate African American slaves and abolish previous slave trades, which has made it possible for them replace the sense of their racial inferiority with that of their racial pride and superiority in the transmission and declaration of the slogans that "black is beautiful".

In a comparative sense, the factual representation of the historical accounts of the racial construction of African Americans tends to be primarily characterized with the superficiality of historical reality owing to the inevitable catering to the needs or demands of the dominant citizens of that society while the authentic and actual revelation of the historical reality in the euphemistic insinuation of the historical truths of American society at that time just as what has been demonstrated in the lines quoted above, has been meticulously poeticized with the profundity of the specific psychological reality of those fellow dark brothers in a historical fashion despite its failure to do so in an explicit fashion and take into account the demonic satiation of those citizens in a close negotiation with the racial reality monitored by those masters who have been poking their noses into the racial affairs of those dark brothers.

The second expectation of this dark brother in this poetic text with respect to the subtle and successive revelation of the cultural reality of American society in that historical context, has a great deal to do with the autonomous and voluntary recognition of the cultural liberty of the African Americans who have been previously repressed in American society at that time in a very consistent fashion in the increasingly frequent and close interaction between them and their masters on account of their success in instilling into the minds of their white masters their instinctive and insightful perception and cognition of the great importance for the protection of their cultural liberty either in an amiable fashion or in an oppositional fashion.

As has been known in the fourth and sixth line of the third stanza of this poetic text, the dark brother who has made efforts to set at the table has bodied forth the eventual recognition of the cultural liberty of the dark brothers the poet has been showing great concern for in his historical poeticization of the cultural historicity of those fellow African American citizens to highlight their cultural liberty in an subversive fashion in reference to their substitution of their masters who have been sitting as their masters at the table in the past while have been forced to act as their servants at present with no guts to boss those dark brothers as has been exemplified in the word "dare" in the sixth line of the third stanza of this poetic text.

Moreover, it can be seen from the second and third line of the fourth stanza of this poetic text that the consolidation and recognition of the cultural liberty of this dark brother have, to a great extent, stood for the cultural access to the deconstruction of the cultural domination of their masters just as what has been indicated in the subversive acceptance and admiration of those masters in a guilty fashion. 
In a predictive sense, the poet has been firmly aware that one day those dark brothers will be likely to darken the vain glories of their masters and dwarf the cultural barbarities of those masters in accordance with the word "shamed" that has been picked up from the last line of the fourth stanza of this poetic text in an insightful fashion. In reference to the historical records of America, in addition to the achievements of a good many dark brothers in other fields, the shameful and admirable recognition of the cultural liberty of those dark brothers by their white masters has also been turned into a reality when Barack Obama has been made the president of America.

In another way, he has become the master of not only dark brothers but also white brothers on account of the successive efforts he has been making on his way to the justification and recognition of his cultural liberty, which has made it clear that the subversive recognition of the cultural liberty of dark brothers has turned out to be possible and feasible as long as they are willing to hold fast to the fulfillment of their cultural dreams. In a way, the poetic historicity of this poetic text has not only revealed the historical reality of American society in that historical context but also predicted that in the future society after that in the creative anatomy of the historical traces of both the development and progress of American society owing to the foresighted ability of this poet to tell the historical truth of contemporary society and predict that of future society in America.

The third great expectation of this dark brother in this poetic text in regards to the profound revelation of this social reality of American society at that time in the explicit articulation of the historical truths implied in the blurring expectations of African Americans, is, epitomized in the racial, political and cultural equality with their master as what to be dealt with in the following three respects.

The first equality as personified in the great expectation of the dark brother depicted in this poetic text is inclined to be seen in the racial equality that has been proposed in a subversive fashion in the third stanza of this poetic text in combination with the very strong desire to take place of his master by sitting at the table where his master has been sitting to showcase the conspicuous superiority to him.

In the sense of racial equality, it can be clearly seen from the strong desire articulated in the second line of the third stanza of this poetic text that after the unbearable torture in the racial discrimination of his white master, this dark brother has aware that it is vital for him to change the enslavement he has been suffering in his repressed interaction with his master on account of his racial identity.

In fact, it is this domestic violence this dark brother has been forced to undergo in his life that has made him getting closest to his breaking point, which is likely to give rise to the abrupt eruption of his indignation for his master and the thought of substituting this demonic master in a violent fashion, for in his indignant mind at that moment, only in this way can he achieve racial equality with his master and make his racial dignity identified with that of his master. 
Of course, a careful reader at the sight of the six lines in third stanza of this poetic text, is likely to sense that in accordance with the historical evolution of America in terms of the exploration that has been made of to solve racial problems between the masters and servants in American families, the only way for those dark brothers to change their miserable fates and experiences, is to outdo themselves and their masters in more than one fashion and to make those arrogant and hegemonic masters submissive to them and voluntary to respect them for the sound and sincere admiration they have been acquiring from their masters on account of their submissive superiority to their previous masters because the genuine dignity they ought to win in their communication with those masters lies not in their violent defeat over their masters but the greater achievements they have acquired from their heroic superiorities to their masters in many a respect to promote the progress and prosperity of America the home they have been staying at with their masters in an evident fashion.

The second equality as personified in the profound expectation of the dark brother in this poetic text in association with the factual revelation of the historical reality of American society at that time has much to do with the explicit insinuation of the very political equality African Americans have been seeking for in their lives.

This expectation can be made available in the determination that has been manifested in the last two lines of the second stanza of this poetic text, for he has been determined to be prepared for the achievement and pursuit of his economic equality so as to enable him to be identified with his master or to be equal with them. For the part of this dark brother, he seems to be aware that his economic growth seems to be the bases for his political growth in that it is his political growth that is likely to bring him political equality with his master.

Grounded on the good preparation to be made in his earlier days for the achievement of his economic and political independence from the frequent domination and manipulation of his white masters in an autonomous way, it is quite possible for this dark brother to lay a very sound foundation for the actual construction of his political identity in the unavoidable and unbalanced communication with his master, for what has been all the more stimulating him to make progress is the burning desire to acquire the real political equality with his white master just as what has been articulated in the last three lines of the third stanza of this poetic text.

In a superficial sense, what has been implied in the great effort to be made for the political identification or recognition of this dark brother at the home of a white master based on his real experience appears to be irrelevant to the historical evolution of African Americans on account of the confinement of the academic horizons or analytical perspectives to the internal qualities of the textual textures of this poetic text.

In a profound sense, what the poet of this poetic text has been voicing in this poetic text through the poetic delineation and representation of the strong desire of this dark brother in both his expectation and exploration of the political 
equality with his white master, in a way, stands for both the strong and profound expectation and the long and miserable exploration of African Americans who have been resisting against and fighting against their counterparts over the political discriminations they have been suffering from in the subverting the social reality of America at that historical moment in the revelation of the historical truths hidden in the historical recounts of the whites, for as one of the spiritual leaders of dark brothers in Harlem Renaissance, it is inevitable for him to permeate into the profound consciousness of those dark brothers in terms of highlighting the strong sense of political justice and equality in the entire American society at that time in the production of his poetic text, and urge them to strive for their own identification or recognition in an ontological fashion.

In essence, the popular transmission of this political consciousness of his poetic text has, to some extent, shed important lights on the presidential growth of African American leaders in most fields. Therefore, what ought to be drawn on from the political awareness or at least the ideological growth of this dark brother in this poetic text, is that it is the ontological growth and transcendence of a group that enable all group members to dwarf or darken the graces, glories or honors of their counterparts, to fulfill their own values, to illuminate others and promote the entire improvement of a society.

The third equality as has been poeticized in the great expectation of the dark brother in this poetic text, ought to be connected with the cultural equality that has been widely believed to be crucial for the cultural independence and transcendence of African Americans with the help of their ontological retrospection on their way to the fulfillment of their cultural equality with their counterparts to the effect that his expectation to achieve cultural equality has stood for his dream of the cultural progress and prosperity of himself. It is this progressive dream that makes him stick to his cultural pursuit in this regard, for if he has no cultural dream like this, he will choose to do nothing to build his cultural identity, dignity and perspicacity but make excuses for his inability to do so.

In line with what has been elaborated in this the second and third stanza of this poetic text, it can be profoundly impressed that there is a sharp contrast between the inferiority of the dark brother and the superiority of him as indicated in the autonomous growth of his cultural awareness. In this sense, the ascendant instead of descendant inclination of the ideological variation of the very dark brother in this poetic text has given rise to both the ideological and epistemological promotion rather than degradation has marked a perspicacious transition of the cultural retrospection.

In essence, the contrast between his inferiority and superiority has been distinguished from each other in a clear and conspicuous fashion in accordance with the ingenuous juxtaposition of the ideological inferiority of the dark brother in the second stanza of this poetic text with the ideological superiority of him in the third and fourth stanza of this very poetic text in an asymmetrical fashion based on his epistemological growth. It is the tremendous difference between the previous cultural inferiority and present cultural superiority of this dark brother 
that lays a very sound epistemological foundation for this dark brother to achieve the cultural equality with his master that enables him to meet his cultural expectation in the process of his own cultural maturity.

Of course, in a historical sense, the poet of this poetic text who has been acting as one of the spiritual leaders of the cultural independence of African Americans like the dark brother of this poetic text, has been eager to see the gradual transition or quick promotion of his dark brothers so as to achieve their cultural equality with their counterparts with the help of the gradual accumulation of the spiritual wealth or the cultural illumination they are likely to acquire from the awakening movement in a cultural sense like Harlem Renaissance because he has been kept quite awake in the experience accumulated from the historical evolution of American culture that it is only the autonomous and ontological cultural growth of African Americans that is likely to be conducive for the fulfillment of their cultural equality with their cultural counterparts.

Based on those analyses, what can be concluded from this poetic text in a cultural sense, is, that it has given a cultural response to the cruel historical reality of American society in the exploration of the cultural truths just as what have been epitomized in the cultural inequality between African Americans and their cultural counterparts and buried in the historical events at that time in consistence with the profound and perspicacious expectation of this poet in building a harmonious society in American to seek for the cultural respect and tolerance between dark brothers and white brothers.

To sum up, it can be seen from the analyses made of in the five respects that the textual interweavement of this poetic text seems to serve as a historical mirror that records either the progression or regression of American society in a euphemistic fashion in association with the poetic imagination of this poet in relation to the development and betterment of American society in more than one sense.

\subsection{The Historical Poeticity of I, Too, Sing America in the Euphemistic Revelation of the Historical Reality of American Society}

From the point of view of the euphemistic generation of both the poetic subtleties and the historical ingenuities of a given poetic text, it ought to be kept in the minds of poetic readers that the historical poeticity of a poetic text is distinguishable from the poetic historicity of it in many a fold.

In this case, it ought to be put that the former has, to some extent, highlighted the poetic qualities of the historical derivation of a given society at a given historical moment while the latter extended the temporal and spatial qualities of the historical imprints of that society in an implicit fashion in association with what to be ruminated in the following three respects in combination with the historical poeticity epitomized in the poetic narration, examination and retrospection of the racial, social, as well as cultural justice of the historical events of the American society in that historical context to reveal the historical truths impli- 
citly told in the poetic rumination of the plausible historical reality of that historical period as what has been dwelled upon in this poetic text titled I, Too, Sing America.

The first thing to be emphasized on in the following analysis to be made of to give an account of the historical reality hidden behind the poetic delineation of this poetic text, is closely connected with the poetic narration of the historical events in the poetic narration of the racial, social, as well as cultural justice of the historical events of the American society in the process of telling the invisible truths that have been intentionally and carefully concealed in the beautification, mystification, as well as divination of the social and cultural vices of a given historical moment in a repressive and fashion and the reduction to the least the vicious effects of those social and cultural phenomenon in that historical context.

In view of the theoretical illumination of new historicists, the correspondent narration of the historical events and facts available in the elaboration and description of the social and cultural phenomenon of a given historical period ought not to be confined to the textual narration of historians, for it is also possible for literary authors to give an account of the historical reality in literary texts just as what has been proposed in the theoretical insights of Louis Montrose who has described the textuality of the history as below: "... history is not a conceived to be a set of fixed, objective facts but like the literature with which it interacts, a text which itself needs to be interpreted..." (Abrams, 2000).

If this elaboration and description put into the shoes the revelation of the historical truths implied in the historical poeticity of those poetic texts, what might occur to the poetic readers of those poetic texts is that the historic poeticity of poetic texts is likely to be found out to tell that the poets of those poetic texts have been bound to make great efforts to design the textual configurations of those texts in the textual construction of their poetic texts in a historical fashion to highlight the narrative reliability and validity of the historical events that have been narrated in those poetic texts in a subtle way to make it exposed to the sights of a good many poetic readers the social and cultural vices of the society they live in for the aim of telling the social and cultural truths woven in the historical reality of a given society in an unnoticeable fashion to get away from the textual censorship of the authorities that are inclined to impose on the conscientious poets of rebellious poetic texts rigid intellectual or cultural persecutions owing to the political incorrectness in their poetic texts.

In fact, it is those persecutions that force insightful poets to give a poetic description of the infamous social vices of a given society in the form of the praises that ought to have been given to the social virtues of it despite its social and cultural injustice to do so in order to distract those authorities from their ideological and epistemological examination. Therefore, what is worth more attentions on the part of those poetic readers is that their meticulous, profound and overall interpretation are in a position to be given of the poetic historicity to make an exploration of the historical poeticity of those poetic texts before those poetic 
readers are able to give a clear and an explicit clarification of the textual evidences and traces of those poetic texts grounded on the special care they have taken of the historical ingenuities potentiated in the historical realities of the given society in which those poetic texts have been produced, for those poets have been decoding social and cultural injustices in the form of encoding correspondent social and cultural justices, and upholding social and cultural conscience in their pretending to be submission to the destruction of it in an indiscoverable fashion.

This is exceptionally true of what has been vividly demonstrated in the second stanza of this poetic text because it has been characterized with the factual objectivity of the historical narration of the historical events in the representations of the bitter experience of the dark brother who has been bossed or even ordered to eat in the kitchen to avoid the social disgraces of his master owing to the notion that his presence in public spaces seems to be likely to darken the interpersonal graces of his master regardless of the very fact that his passive absence from the interpersonal communication of his master has bodied forth a kind of racial humiliation because the poet of this poetic text has based his poetic production on the implicit presentation of his historical conscience to his poetic readers as opposed to the reluctant subjectivity that has been loaded with the textual production of the historical texts produced by the timid historians who dare not tell social and cultural truths of the society in which they have lived in their studies and cannot but choose to distort the historical truths of that society in that historical context to go on with their disgraceful lives by covering the social and cultural vices of that society to win the favor of the social dominators at that time by singing hypocritical praise for or at least speak highly of those dominators to earn a living because of their inadequate language competence that prevents them from distracting the awareness of the authorities who have taken charge of censoring the political correctness of their historical texts.

For one thing, it can be sensed that this poetic text has been playing a more important role in the revealing the historical realities of American in the process of unveiling the very historical truths of American society at that time, awakening the social and cultural awareness of all African American dark brothers, as well as reminding the authorities of the social problems of America in an ingenuous fashion as has been epitomized in the poetic depiction of both the racial and cultural discriminations those dark brothers have been suffering from their asymmetrical contacts with their masters and the social and cultural manipulation of those masters in order to continue or at least sustain both their demonic and hegemonic control over the ideological and epistemological growth of those dark brothers.

For another thing, it has been believed to be less fortunate than this poetic text that a variety of historical texts have turned out to be insufficient for the factual transmission of the historical truths into the profound consciousness of their readers owing to both the academic timidity and linguistic inferiority of the his- 
torians who have no guts to tell the truths in order to avoid the barbarian angers of the dominators of American society at that time and are less qualified to reveal the historical realities in an ambiguous fashion to weaken the racial ambivalences between those dark brothers and their masters owing to the indifferent attitudes they have held towards the sound bitterness of those dark brothers and the helpless timidity they have been seized for the authorities of those dominators in that society.

The sharp contrast in the narration of historical events between the texts of intelligent poets and those of helpless historians has to a great extent told poetic readers and historical readers that in a comparative sense, the former are brave and smart enough to represent the profound truths of American society at that historical moment while the latter too timid and indifferent to call a spade a spade in the revelation of the cruel historical realities at the sight of various unfair social and cultural phenomenon.

For the sake of this, the former are likely to be forgotten on account of the impossibility for the poetic readers to have a true understanding of what they really want to say in accordance with the possible analyses of or inferences from what they have said in both the subtle and unintelligible configuration of their poetic texts and the latter inclined to mislead their readers as a result of their keeping those readers from knowing the historical truths of American society so as to cater to the hegemonic demands and orders of the dominators of that society and maintain the political security for those dominators.

In other words, the former have prevented the extensive transmission of historical truths in an unintentional fashion while the latter have concealed them in an intentional fashion. Both of them are likely to give rise to the historical agnosticism if there will be great poet to recognize the incredible strokes of the former in his overall exploration of both the literal implication and the liberal implication of this poetic text and the treacheries of the latter in the insightful examination of the poetic narration of the historical truths in the poetic text of this poet and the inaccurate transmission of those truths in the historical texts of historians. If so, both of them have been doing harm to the social and cultural prosperity of America in the future because remarkable development and progress of American society in the future of America cannot be unconnected with a very profound perception and cognition of previous historical truths of previous society.

In this case, it will be extremely important for both poetic readers and critics to acquire international poetic wisdom to develop their own poetic wisdom from their extensive and intensive readings of the poetic texts around the world, to broaden their poetic horizons on the basis of the poetic illuminations they are likely to acquire from the critical acumens of the poetic critics throughout the world, and enrich their poetic insights to enable them to get close to the complete discoveries and rediscoveries of the very truths buried in this poetic text. In this sense, what cannot but be done is to try every means to help poetic readers and poetic critics to highlight their poetic literacy to make their way to their in- 
sightful recognition of the historical truths hidden behind the textual distractions that have been preventing poetic readers and poetic critics from having a very true understanding of the historical realities after seeing through everything that has been adopted to decorate the historical phenomenon and perplex those readers and critics that have been characterized with either the factual narration or fictional narration of the historical events in the poetic text of this poet and the historical texts of historians.

With what has been analyzed taken into a good account, it can be inferred right from the factual narration of the historical events in the second stanza of this poetic text that the poetic delineation of the historical reality in terms of the racial discrimination and isolation of the African American dark brothers have suffered from their passive contacts with their demonic masters in American society at that time, tends to tell much profounder truths of American society in comparison with what has been hidden in the fictional narration of the historical texts that have been produced to meet the dominant willingness of the dominators of that society at that historical moment.

The second thing to be concentrated on in the following critical analysis to be made of the historical reality that has been hidden behind the poetic deliberations of the ingenuous textual configurations of the historical evidences and events to be chosen to enrich the historical insights and highlight the historical authenticity of the historical reality represented in the narrative construction of this poetic text, is closely connected with the poetic examination of the racial, social, as well as cultural justice of the historical events of the American society at that historical moment for the historical reconstruction of the racial identity and dignity of the African American dark brothers just as what has been embodied on both the ideological and epistemological growth of the dark brother who have been suffering from both physical and spiritual tortures in the process of the temporal progression and spatial expansion of his life.

As has been shown in the second and third stanza of this poetic text, the poet has chosen a domestic scene or situation as a typical fragment and makes it a domestic microcosm of the miserable lives of this dark brother to make the point of the factual authenticity that can be used to echo the historical objectivity of the poetic construction of American society and the poetic reconstruction of the social and cultural identity and dignity of African American dark brothers who have been made to spend the vast majority of their time at the home of their masters on account of their inability and illiteracy to take a decent job in the society that has been dominated by their masters who have been robbing them of the right correspondent educational opportunities they ought to have taken to improve their literacy and change their changeable lots as a result of both the internal strong and sound worries about the ideological and epistemological independence of those dark brothers from them. Therefore, this choice has to some extent made it reliable that the textual production of this poetic text is to be fulfilled on the road to the elimination of the historical subjectivity as has believed to be carried in the historical texts of historians. 
In this sense, the movement of this dark brother from the sitting room of the house of his master to the kitchen of it as seen in the second stanza of this poetic text, has stood for both the sharp and abrupt deterioration of the social and cultural identity and dignity of the vast majority of those African American dark brothers who have been enslaved and imprisoned at the homes of a variety of masters, for the domestic violence in the form of both domestic enslavement and imprisonment in both physical torture and spiritual confinement has been becoming an overt secret in American society at that time owing to the sustainable existence of slave trade and the failure to accomplish the thoroughness of abolitionism before and after the civil war in the history of America. So to speak, the meticulous poeticization of this domestic fragment of the lives that have been undergone by the dark brother in this poetic text is in a position to be considered as the archetypal representation of the objective reality of American society in that the historical poeticity best exemplified in this poetic delineation has been providing almost all poetic readers of this poetic text with a strong sense of poetic authenticity.

In line with the analyses made above, it is likely to cross the minds of the readers of this poetic text that the poeticization of the historical events in the conditional description of the lives of the dark brother of this poetic text has helped the poet of this poetic text to make his way to the poetic reliability of his texts that have been devoted to the revelation of the cruel historical reality of America at that time apart from both the inspiration and illumination of all African American dark brothers who have to pick up their courage to reshape, to rebuild or reconstruct their social and cultural identity and dignity in American society when they are faced with both the social and cultural brutalities in their unsocial and uncivilized lives, for the poeticization of this domestic fragment is the most objective exemplification of the sweet bitterness or in another way the bitter sweetness of the African American dark brothers who are supposed to have been bearing in their minds a very strong desire to give a consistent response to the awakening voices of this poet just as what has been definitely articulated in the first stanza of this poetic text and emphasized in the last stanza of it in the construction of the social and cultural identity and dignity of those African American dark brothers.

In the case of the poetic validity of the historical reality of American society at that time in the authentic and adequate delineation of the miserable and brutal state of the psychological reality of that society rooted in the popularized racial discrimination in accordance with the domestic fragments of those dark brothers, this poet who has been serving as one of the spiritual leaders or prophets of those dark brothers, has given a good presentation to both the strong irritation and indignation for the unfair social and cultural phenomenon that has been superficially decorated with hypocritical considerateness of their hegemonic masters who have been trying every means to cover their social and cultural vices in the name of kindness.

In distinction from the fictional and flattery narrations, memories, descrip- 
tions as much as interpretations of the social and cultural reality of American society existing in the textual qualities of the historical texts of most historians, the textualization of this poetic text ought to be considered as a far-sighted approach for the poet to give an examination of the social and cultural justness with the help of the acoustical, lexical, syntactical, textual as well as discursive ingenuity in the maximization of the objectivity of the historical events poeticized in the textual configurations and constructions of the historical conscience of this poet that has been rooted in the strong social, cultural and moral conscience of him in promoting the social justice of American society based on the historical samples of previous American societies and resist against the subjectivity of those historical events just as what has been intentionally fictionalized in the social and cultural construction and reconstruction of the social and cultural images of American society owing to the great efforts that have been made to meet the sycophantic needs of the timid historians who have been lost in the distortion of the historical truths of that society in a blind fashion in order to cater to its dominators, to speak for them and make a living regardless of the harm they have done to those dark brothers and the risks for them to be lost in the wills of those dominators who have been bossing them in a very hypercritical fashion.

In this sense, the historical reality related to the correspondent lives of those dark brothers have been distorted by the mountainous misinterpretations and misconceptions of those historians who have been fed up with a variety of the preconceptions of the dominators of American society in that historical context in exaggerating the racial inferiorities of those dark brothers and the superiorities of their masters in the evolutions of the history of African American dark brothers. Hence, it is those factual distortions in the recounts of the historical events of those dark brothers that make it very important for the poet of this poetic text to raise the extensive attentions of those dark brothers to fight against the historical falsity of the historical constructions of those historians in accordance with the historical truths told in the meticulous efforts this poet has been making in the production of this poetic text to represent the historical reality of America in that historical period.

Having taken into consideration what has been analyzed above in the light of the poetic examination of the racial, social, as well as cultural justice in the narration of the historical events of the dark brothers in American society at that historical moment, poetic readers and critics are supposed to have a good knowledge of the fact that the dark brothers have been suffering from the narrative injustices in the intentional and unjust textualization of their historical events on account of the narrative distortions of those historians, and the social and cultural inferiorities of those dark brothers is nothing but a narrative aftermath or product of those timid, slippery as well as sycophantic historians who have been performing narrative victimization regardless of their sycophantic narrative concealments of the cultural and social vices of the social dominators of American society at the cost of turning those dark brothers into narrative victims with- 
out taking into considering their narrative guilt in stigmatizing the historical image, consciousness, and superiority of those dark brothers who cannot but stand the narrative injustice in the form of narrative stigmatization of the historical narration of historians before their rational awareness of the harm it is likely to do to the historical growth of them and the importance for them to take actions to resist against and fight against the narrative stains engendered in those unreliable historical narration in the historical texts of historians.

The third thing to be stressed in the following critical analysis to be made of to give an actual account of the historical reality woven behind the poetic delineation of this poetic text, bears much relevance to the respective poetic retrospection of this poet in his historical production of this poetic text in terms of the racial, social, and cultural injustice that tends to be available from the historical events of the American society.

This has been rooted in the poeticized retrospection of the historical experience of the dark brother that has been characterized in this poetic text to figure out the correlative social and cultural significance of African American dark brothers as what has been ruminated in a poetic fashion in the second stanza of this poetic text because he has begun to think about the accumulation of his physical power and spiritual intelligence to fight against the domestic violence he has been suffering from the disgraceful and shameful isolation of him from interpersonal communication with the guests of his decent master to avoid the communicative disgrace caused by his unnecessary presence by giving them a tolerable tolerance in pace with his profound meditation on something that matters most for his resistance against this communicative discrimination and humiliation. In this sense, his discriminative tolerance is in a position to be considered as one of the important actions he has taken to achieve his social and cultural independence in social and cultural communications in agreement with what is similar with the incredible miseries of the vast majority of African American dark brother in American society at that time.

As has been discussed above, the poeticized contemplation of the discriminative existence of this dark brother has, in a way, stood for the historicized reflection of this poet in his historical construction of the racial identity and dignity for a very large number of African American dark brothers who have been enslaved, confined as much as imprisoned either in a physical and spiritual fashion in almost all corners of American society at that time. In other words, it has come to his mind that it is quite urgent for him to enlighten those dark brothers to find out correspondent ways to achieve their physical and spiritual liberation in the course of the illuminative textualization of his poetic text by giving a historical response to the fond sweetness they are likely to taste when they have gotten far away from the restraints of their masters in accordance with what has been expected to make those masters to show their admiration for the racial beauty, charm and value of those dark brothers who ought to have been playing an important role in upholding, promoting and highlighting their instinctive and insightful racial aestheticism by enabling their masters to have a very ge- 
nuine understanding of the guilty mistakes they have made in belittling their servants and slaves in a brutal fashion.

With this historical awareness of the poeticized historical events embed in this poetic text, it is a great deal bound to be made possible for a good many poetic readers and poetic critics to have a good understanding of what has been illuminated in the three lines of the fourth stanza of this poetic text, for it is unavoidable or inevitable for them to take into account the approaches available and possible to change the miserable lots of those dark brothers in American society as long as they are able to associate the despaired experience of this dark brother depicted in this poetic text with that of those dark brothers of American society in that historical context in which slave trade has been popularized in a legal fashion just as what has, later on, been reflected or recorded in a variety of historical archives, documents and reports.

In addition to the historical analysis of this poetic text as has been made of above, a variety of other poetic texts are also supposed to be reexamined in a historical sense to dig out the historical truths distorted in the textual elaboration and clarification of many a historical text produced by historians, to show great concern for the virtuous changes of the lots of all dark brothers in American society, to rebuild the racial values of those dark brothers and protect the racial dignity of them in the positive interpretations of the linguistic, semantic as well as discursive ambiguities conceived in the ingenuous production of those poetic texts, for poetic texts are the subtlest and smartest ways to tell profound historical truths in an unnoticeable fashion compared with other literary texts and historical texts that have been devoted to the revelation of the superficial realities of American society at that time.

That is because this kind of historical analysis of the poetic texts rooted in the similar historical contexts as has been exemplified in this poetic text, is conducive for poetic readers and poetic critics to quicken the development of the historical awareness in both their analyzing and criticizing practices of poetic texts, and highlight their analytical and critical conscience that has been based on the sustainable stimulation of their social and cultural conscience in their decoding their historical complexities that have been implied in a covert fashion in the semantic ambiguities or even amiable ambivalences of poetic texts, and encoding the correlative social and cultural justices that have been blurred in the historical narration of the historical texts of a good many historians who have preferred to make it very impossible for their readers to have a good understanding of the objective history of the society they have lived.

From the point of view of this historical analysis of this poetic text as interpreted in this essay, the profound and perspicacious exploration of the poetic revelation of the historical reality of American society in combination with the historical told in this poetic text, is bound to broaden the analytical and critical horizons of a lot of poetic readers and poetic critics in urging them to refer to the autonomous or ontological retrospection of the dark brother in this poetic text to give rise to his physical and spiritual liberation, and that of those dark 
brothers he has been bodying forth in American society at that historical contexts in addition to the analytical and critical retrospection of the historical profundity of this poetic text in the representation of the profound historical realities that have been concealed in the historical superficialities of historical texts.

To sum up, the historical poeticity of this poetic text titled I, Too, Sing America in terms of its poetic narration, examination and retrospection of the racial, social, and cultural justice of the historical events of the American society in the historical context it has been produced, has played a very indispensible role in the euphemistic revelation of the historical reality of American society owing to the poetic conscience and sense of integrity of this poet in his promotion of the historical responsibility in poetic production and his rigid adherence to the theoretical stands of the historical euphemism in both the ideological and epistemological interweavement in the semantic transmission and permeation of his historical insights into the textual textures of this poetic text.

\subsection{The Correspondent Poetic Strategies Taken to Articulate the Historical Reality of American Society in I, Too, Sing America}

On the foundation of the previous and profound focalized analyses of the historicization of this poetic text and the poeticization of American in connection with the historical events of American society that have been insinuated in the textual production of this poetic text in the temporal context of American abolitionism, what ought to be aware of in an overall fashion in the correspondent justification of the academic proposition proposed at the outset of this essay is to make an important exploration of the poetic strategies this poet have been taken in the textual construction and production of this poetic text in both the historicization of his poetic production and the poeticization of the historical realities that have been insinuated in this poetic text to highlight the very important role he has been playing in the insinuate and invisible exemplification of historical truths of American society at that historical moment in the textualization of the historical context of this poetic text in consistence with the theoretical illumination acquirable from the historical contextualism demonstrated in the textualization of the historical realities in poetic production just as what to be elaborated in a respective fashion in relation to the theoretical insights prevailing in the academic views of Stephen Greenblatt because what has seemed to come to the mind of this poet is that although a great many changes have taken place in American society at that time, there still appear to be a variety of ideological and epistemological barriers that have been preventing those African American dark brothers of American society from the liberal and legal acquisition of their social and cultural liberty, equality, identity and dignity and the promotion of ubiquitous fraternity they have been expecting their masters of for a long time.

For the sake of those preventions in social lives and domestic lives of those dark brothers, it is quite necessary to make an exploration of the correspondent strategies the poet of this poetic text has taken to historicize the social and cultural truths that have been undermined in the superficial manifestations in the 
historical recounts of a large number of historians in line with the theoretical edifications of Greenblatt, and make a profound analysis of the strategic decentralism this poet has instilled into the minds of his poetic readers and poetic critics to unveil the true historical realities of American society in the process of resisting against the ideological and epistemological centralism in order to reach their selfish aim of repressing those dark brothers through the domination and manipulation of the majority of historians to speak for them and hide the historical truths that ought to have been told in the representation of those historical realities just as what to be clarified in the following two folds to enable his poetic readers and poetic critics to have a true understanding of the social and cultural vices of the social and cultural dominators of American society in the historical context this poetic text has been produced.

In accordance with those theoretical illuminations perceived above, what is in a position to be noticed in the actual elaboration of the ideological and epistemological profoundness that has been meticulously and ingenuously embedded in the quietness nurtured to swallow or weaken the strongest and soundest desire conceived in the tranquil mind of this poet in his production of this poetic text to get far away from the cruel examination of the authorities and ensure his poetic security in the revelation of the historical truths rooted in the historical realities concealed in both the social and cultural vices and ills of American society at that time, is that the poetic strategies this poet has taken to reach those aims bear a great similarity with what has been suggested in the theoretical views just as what to be dwelled upon based on the two historical explanations to be made below to the poetic insinuations of this poetic text.

On the one hand, it has been noted in the theoretical elaboration of Stephen Greenblatt that the unevenness between the subversion of the unvoiced and the repression of the voiced is an important strategy the voiced dominators of a given society have tended to take to swallow the possible voices of the marginalized and unvoiced group of this society so as to distract themselves from their dangerous retrospection from their previous stupefaction in line with the high possibility for them to have a good control over the textual mechanism exemplified in the hierarchical orders of both literary and cultural productions that have been believed to serve as an important way to prevent the ideological and epistemological truths of the former from being told in a clear fashion and distance their political awareness from their ideological and epistemological promotion in the form of political examination to test the acceptable political correctness of literary and cultural texts and get rid of the political incorrectness of them in consistence with the potential and possible correspondence between the aesthetic production of those texts and the hegemonic vices of the historical realities of that society. To blur the textual censorship of the authorities, writers, especially poets have to make the best of their versatilities to avoid literary and cultural persecutions and sustain the important and insightful textual continuities of those texts. 
In the case of this, what the poet of this poetic text has to do is to destroy the balance between the articulation of the subversive desires or motivations of the unvoiced and the repressive intentions of the voiced through the subtle interweavement of them in his poetic manifestation of the favorable patriotism of the latter to voice the subversion of dark brothers to their master in a submissive fashion with the help of the degradation of the strong anger or indignation of those dark brothers in a quiet way proposals and hide their questions of the ideological and epistemological justness or fairness of the social and cultural dominators in American society in that historical context ideology to leave their poetic readers a deep impression that the poetic representation of the historical realities of that society as seen in this poetic text seems to curb the inevitable releases of the dissatisfaction of the former with what they have been forced to be faced with in their lives, and the cruel repression of the latter tends to be so effective that the subversion of the former has been confined to the least so that the latter have nothing to do but choose to be submissive to the latter, for the dark brother depicted in this poetic text has no choice but choose to sing highly of his master both at the beginning of this poetic text and at the end of it to the effect that they have no more to say save that "I, Too, Sing America" from the beginning to the end. In this sense, what this poet wants to say most is that the American society at that time has been manipulated in the masters of African American servants and slaves in spite of their strong resistance against abolitionism.

With respect to the similar domestic scene in the destruction of this balance, it can also be found in the second stanza of this poetic text, for the dark brother in this stanza has given a hospitable response to the domestic violence of his master who has been hostile to him on account of his racial disgrace in presence of his master by giving his master friendly smile at the impolite discrimination that has been best seen in his absence from the social and cultural communication of his master to avoid the hostile doubts that are sensitive in the mind of his master. It seems that the interpersonal graces of his master as what has been embodied in the peaceful interaction between him and his master in the same stanza of this poetic text has based on his absence from the decent interpersonal communication of his master and his active absence seems to be crucial for him to hide his strong desire to subvert the domestic violence of his master who has been accustomed to both his hegemonic presence and the discriminative absence of his servant. To a similar extent, it is the case with what has been historically observed in the tolerable and bearable forgiveness of the African American dark brothers in American society. Therefore, it can to be said in an explicit fashion that the subversive submission of the dark brother in this poetic text to his master has turned out to be very important for both the overall and rigid ideological and ideological examination of the authorities, for it has broken the balance mentioned above, avoided the poetical persecution of this poet and insinuated the historical realities of American society in that historical period.

Based on the correspondent and correlative historical analyses that have been 
made of the two cases mentioned above, it can be concluded in a natural fashion that the destruction of the balance dealt with above has turned out to be an effective fashion for the poet of this poetic text to give a clear account of the possibility for him to get away from the political disturbances and nuisances of the authorities who has nothing to do but impose upon him their social and cultural repression to have a much more tight control over his ideological and epistemological promotion in the form of poetic persecution if they have been made aware of the his strong subversion before their success in representing the brutal truths of the historical realities of American society at that time in compromise with what has been told in this poetic text in an unnoticeable fashion.

Therefore, judging from this conclusive discoveries, it turns out to be evident that in the specific and special historical context of the textual production of this poetic text, one of the most perspicacious strategy this poet has taken to account for the historical realities that have been distorted in the historical texts of a good many historians is his purposeful and precious destruction of the previous balance between the hegemonic repression of the master of this dark brother to prevent them from having a true understanding of the very truths blurred in the narration of the historical realities that has been sensitively believed to have been playing an important role in the concealment and distortion of those truths, and his subversion to the demonic domination and manipulation of his master by turning into subversive submission in the form of the poetic patriotism voiced in a reluctant fashion his real motivation to quicken the awakening process of African American dark brothers who have been leading miserable lives in various corners of American society in that historical situations at the cost of adapting the semantic insinuation of his poetic production to the plausible submission of his poetic configuration to the dominant awareness of the dominators of American society in a very untraceable way to make his way to the factual revelation of the historical realities under the safe protection of this disguising submissions in despite of his strong will to highlight the racial aestheticism of those dark brothers.

To be short, it is those submissive disguises practiced in the semantic generation of this poetic text that have been playing an important part in helping this poet to protect himself against the poetic persecution of the authorities in order to reach his aim of voicing the loudest and most furious voices of African Americans in a mild way, realizing their basic physical and spiritual needs of striving for their innate equality and liberty to protect their racial identity and dignity in an implicit fashion, as much as promoting the overt progress and prosperity of American society at that historical moment in a covert fashion in order to pacify the clamorous suppression of the dominators of that society and develop the subversive awareness of those dark brothers who have been expected to be able to promote the virtuous development of American society and prevent the vicious degradation of it in the process of abolitionism and ideological renaissance. 
In this sense, what this poet has invisibly done in this poetic production is favorable for the subversive and successive development of the racial pride of African American dark brothers in American society and the effective, insightful and ingenuous reduction of the repressive sensitivity of the authorities of that society at that time, for this symmetrical destruction has eventually turned out to be in consistent with the correspondent theoretical inspiration of new historicism in that this poetic text does produce an authentic poetic history or at least promote its progress owing to the flexible application of the powerful and perspicacious strategy of breaking the ideological balance between the suppression of the dominators of that society and the subversion of those dark brothers those poet has been awakening in his poetic careers in pace of running away from the poetic persecution he might have been suffering from as many other men of letters.

On the other hand, it ought to be kept in the minds of the poetic readers and poetic critics of this poetic text that the profound absorption of the theoretical insights from the theoretical clarification of the two important conceptions in terms of negotiation and self-fashioning in the theoretical explorations of Stephen Greenblatt has to be considered as one of the most effective strategies this poet chooses to respond to the domestic brutalities that have occurred in the miserable lives of African American dark brothers because what has been performing and persisting in his poetic production is quite coincident with the theoretical emphases of Stephen Greenblatt who has made the point of the barbarian fact that the voice-lost group members of a given society are likely to be enabled to be identified with the voiced-gained group members of that society in literary and social order owing to the appropriate balance that has been struck between them.

The reason for this likelihood is that this new historicist has held that the significations of negotiation cover consultation, transmission, meditation as much as integration applicable in the autonomous construction of character image through self-fashioning for the embodiment of the contention and competition of varied forces in the ontological formation, identification and constructions of the members of the former group to protect their identity and dignity, while those of self-fashioning is concerned with the acquisition of something which has been accused of such as paganism, barbarianism, witchcraft, eccentricity, adultery, or something that tends to be terrible to be heard of like pagan, barbarians, witches, adulteress, traitor and as such in that those horrible things can be fictionalized, found and even used to attack and destroy the members of the latter group.

In the case of the correspondent analytical samples in the confrontation of the dark brother with his master in this poetic text, it has been carefully and reasonably manifested in the formations, identifications and constructions of the images and values of the dark brother and his master in the third stanza of this poetic text that the identity and dignity personified in the images of the two op- 
posite characters in this poetic text and the correspondent significations in those respects are inclined to be produced in a gradual fashion in the repetitive competition between them in line with the sharp confrontations between them in the historical realities of American society in that period in the light of the differences between the social and cultural liberty and equality existing in their interpersonal interactions, for the unilateral formations, identifications and constructions of the protagonist of this poetic text, are the constructive products of his own repetitive suggestions and interpretations of his own identity and dignity even if it has turned out to be too relative to distinguish the protagonist of this poetic text from the antagonist of it on account of the changeability of the social and cultural stances and attitudes between this dark brother and his master. In other words, the protagonist of this poetic text is likely to be turned into the antagonist of it in compromises with the changes of the social and cultural stands.

To highlight the real aim of revealing the historical realities epitomized in the acceptable confrontations between the African American dark brothers of American society at that time and their masters, the poet has to take into a good account the pacifications of this opposition by reducing or confining it to the least to raise least attentions of the authorities of American society in accordance with the racial eclecticism that ought to be persisted in the semantic negotiation and recognition of the respective values and contributions of the dark brothers and their masters of American society in both the valuable and meaningful configurations of their respective significance in his poetic production to help those dark brothers beware the great importance for them to acquire both their own racial identity and dignity through the appropriate development of their ontological and autonomous awareness and prevent their masters from their over-exaggeration of their impact on American society at that historical moment by owing the social and cultural values of either of them to the combination of the autonomous recognition of themselves and the oppositional recognition of their counterparts in digging out the very truths existing in the oppositional realities between them just as what to be demonstrated in the following analyses.

That is because a meticulous meditation on the appropriate domination of the social and cultural confrontation will enable the poetic readers or poetic critics of the same stanza of this poetic text to shut away from both the ideological and epistemological inscrutability of the historical texts of most historians in comparison with the semantic clarity and linearity of this stanza and make it discoverable in an effective and evident fashion that in American society over that historical period, there have been inclined to be two binary opposite parties who have been representing two distinctive groups of American society at that time: one is the dark brothers and the other their masters. For the part of the former, it is almost impossible for them to think of their subversion in a furious fashion by taking radical actions to fight against domestic brutalities of the latter, for the latter have enabled and entitled themselves to have a very tight control over the former. 
In this case, it is unwise for the former to release their indignations and protect their racial identity and dignity in an unsophisticated fashion and much more unwise for the poet of this poetic text to give an irrational account of the harsh historical realities of the interpersonal ruthlessness of American society before his discoveries and deliberation of the right strategies to sharpen the unbelievable profundity of the social and cultural confrontation between them in an untraceable fashion because any rush actions available to reach this aim will give rise to the rigid poetic persecution in the textual examination of his poetic text in a political sense. If something sensitive found out in his poetic text, it is far more impossible for him to show his concern for the former and his furious hostility to the latter, let alone uphold social and cultural justice in his poetic production because it is even impossible for him to make sure of his personal security when he has to be faced with the poetic persecution or even the violent assassination of the latter who is also the dominator of the social history at that time.

Therefore, in this historical situation, the appropriate strategy for his poetic production is to negotiate the historical cruelties of that society with his own poetic conscience that he has been adhering to in order to uphold the precious social and cultural fairness in his own poetic production by reaching this aim in an implicit fashion, for it seems to make a concession to the authorities of that society but it actually highlights the social and cultural unfairness of the domination of the latter and enables experienced poetic readers and poetic texts of his poetic text to have a true understanding of his situations in which he has been deprived of his innate and intuitive freedom of speeches. That is because this liberal deprivation is, on the contrary, likely to come to the mind of his poetic readers and poetic critics that they are supposed to take the deprivation itself as an ironic evidence for the demonstration, exemplification and justification of the indescribable or unutterable miseries of the former and the unimaginable cruelties of the latter.

In fact, the autonomous abandonment of the intellectual conscience or bottom line of the majority of historians in the textual production of their historical texts in that society has in an indirect fashion permeated into both the unrighteous conscience and consciousness of poetic readers and poetic critics if they have been enabled to have the very kind of perspicacious imagination to do so in their poetic education that is designed to develop their unusual poetic perception and cognition to sense the historical injustice or unfairness in either historical texts or poetic texts, for the sensitivity of this poetic perception and cognition will enable them to know that the more implicit the poetic text of this poet becomes, the more violent the society it has been located in is and the more cautious the poet are forced to be in his production of this poetic text, the more brutal the dominators of that society are. In accordance with this analysis, what is likely to occur to those readers and critics is that one of the best strategies for this poet to insinuate the harsh historical realities of that society to unveil the 
historical truths of that society in an ingenuous and insightful fashion is to make a best negotiation between the manifestation of his poetic conscience and the thorough revelation of the cruel realities of that society and that it is certain that the occasional failure or inability for him to achieve the poetic thoroughness in this revelation is a more persuasive evidence for the justification of the historical injustice that have been hidden in the superficial beautification of those enslaved and imprisoned leaned men in that society. Judging from this analysis, it ought to be kept in a clear fashion that the negotiation of this poet in his production of this poetic text is a successful one, for it has enabled him to get away from the fatal danger that he might have been faced with and make his way to the production of more ingenuous poetic text to enrich his poetic careers and challenge more unusual poetic wisdom in more violent historical context.

One more thing to be noticed in the perception of the historical truths of the second stanza of this poetic text, is, that the sharp contrast between "they" and "I" or "me" has, in a way, suggested the tremendous gap between the African American dark brothers and their masters and this gap has made it clear in an invisible fashion that the latter are bound to have great difficulty in making greatest efforts to resist against and fight against the hegemonic violation of their masters over the manipulation of their liberties and even their lots at random in the form of deprivation, exploitation, discrimination, suppression as well as stupefaction before their successive and sufficient accumulation of the unnoticeable and unimaginative power to do so in connection with their achievement of both physical spiritual and growth grounded on their profound perception of the implicit poetic wisdom buried in the textual construction and semantic representation of this poetic text as has been epitomized in cautious formation of the particular self-fashion in his poetic text.

To sum up, it has been proved to be feasible and reasonable in an overall fashion for the justification of the academic proposition of this essay that that the factual historicization of both the social and cultural injustice of American society in the textualization of this poetic text, the ingenuous poeticization of the true historical cruelties of American society at that time in the historical contxtualization of this poetic text and the strategic presentation to the historical truths of the confrontations between African American dark brothers and their master in the valuation of the epochal quietness of the historical furies at the bottom of those masters at the cost of the ingenuous devaluation of the historical soundness in the clamorous minds of those dark brothers to insinuate the unbearable brutalities of historical realities of America over that historical moment before and after the illegalization of slave trade.

\section{Conclusion}

By and large, the euphemistic insinuation of the historical realties of American society in the textualization of this poetic text has turned out to be available in accordance with the three major findings to be summarized below one after 
another.

The first major finding of the historical justification of the cruelties of American society lies in the implicit and wise historicization of the social and cultural miserable experiences that those African American brothers dark brothers have been suffering from the oppression, discrimination and deprivation of their hegemonic masters in the domestic violence widely to exemplify and typify in the exploitation and deprivation of their inborn rights and liberties in their inevitable interaction with those fiendish masters for the aim of upholding social and cultural justice in his poetic production based on the profound awareness of the poet of this poetic text in highlighting the historicity of this poetic text.

The second major finding of the historical justification of the brutalities of American society is available in the unmatchable poeticization of the historical realities of American society in the ideological implantation of the subversive or at least reactive awareness into the enslaved and imprisoned minds of those dark brothers to raise their close attention to the importance for them to resist against and even fight against their masters in a relentless way or in an indomitable fashion so as to quicken the reconstruction of their own social and cultural identity and dignities in an intelligent fashion on the basis of their acute sense of the important role the subtle poeticity of historical realities has been playing in the historicization of the historical truths in the production of this poetic text owing to its poeticized contribution to the representation of the social and cultural darkness of American society in that historical period as has been manifested in the domestic violence of the masters of those dark brothers.

The third major finding of the historical justification of the sound ruthlessness of American society, has most to do with the smart strategies that have been taken in the production of this poetic text in terms of the intentional destruction of the asymmetrical balance between the subversion of this dark brother and the repression of his master in this poetic text to place a great emphasis on the articulation of profound subversion in a submissive fashion to change the miserable lives and tragic lots of African American dark brothers, and the far-sighted negotiation between the historical cruelties of that society with his own poetic conscience in the application of the essential connotations of self-fashion into the poeticization of the unjust historical events in the textual production of this poet.

Based on the correspondent analyses made of to support those three major findings of this essay, it can be concluded in a very reasonable and feasible fashion that the successive and systematic justification of the major academic proposition as clarified at the beginning of this essay has turned out to make senses and make a lot of differences in the poetic representation of historical realities in the production of this poetic text.

Despite the unpredictable implications of this essay, two of them are supposed to come to the minds of a good many poets and the poetic readers or poetic critics of their poetic texts according to the following two elaborations of those two implications. For one thing, the justification of the poetic insinuation of histori- 
cal truths is likely to give rise to the new challenges for those poets because they have to sharpen their insinuation to unveil more historical realities and protect their own securities. For another, it will take much more insinuating versatility and perspicacity for those poetic readers or poetic critics to have a true understanding of the more euphemistic insinuation of the historical truths in those poetic texts.

Great efforts as have been made to maximize the academic values of this essay, inevitable mistakes and limitations are bound to exist in this essay due to the superficial understanding of the critical insights of previous poetic critics and the theoretical insights connected with the historicity of poetic text and the poeticity of historical realities in American society in promoting the historical presence of poetic production in resistance against the poetic absence from the textual production of historical texts at the cost of the abandonment of the moral bottom line or breaking point of the academic conscience of historians.

In correspondence with the critical and theoretical limitations of this essay, greater efforts will be bound to be made to sustain the academic continuities of the studies of this respect in spite of the possible and preventive difficulty; the author of this essay might have in getting rid of the unpredictable discontinuities in future studies. In addition, much forgiveness will be expected of scholars and experts in this field if there is possible disrespect for or offense for the academic views of our great forbears and forerunners of both at home and abroad due to the critical ideas proposed in this essay.

\section{Conflicts of Interest}

The authors declare no conflicts of interest regarding the publication of this paper.

\section{References}

Abrams, M. H. (2010). A Glossary of Literary Terms (9th ed., p: 219). Beijing: Foreign Language Teaching and Research Press.

Barr, A. (1996). Black Texans: A History of African American in Texas (p. 16). Austin: Texas University of Oklahoma.

Bone, R. A. (1998). The Harlem School. In R. A. Bone (Ed.), The Negro Novel in America (pp. 65-94). London: Yale University Press.

Brooks, G. (1986). The Darker Brother. The New York Times (Book Review), 10, 7-9.

Emblem Jr., E. S. (2013). Freedom in the Thought and Work of Dr. Martin Luther King, Jr. (p. 4). Ph.D. Thesis, Waco: Baylor University.

Hitchens, C. (1987). Whiteman's Darker Brother. The Observer, 1, 22.

Li, G.-J., \& Luo, J. (2018). A Culturalist Interpretation of the Dark Brothers' Sound Bitterness in Hughes's I, Too, Sing America. Studies in Linguistics and Literature, 2, 27-55. https://doi.org/10.22158/sll.v2n1p27

Liu, L.-H. (2000). Langston Hughes and His Dream. Journal of Mudanjiang Normal University (Philosophy Social Sciences Edition), 1, 35-37.

Liu, W. (2007). Sorrows and Promises: The American Dream in Langston Hughes's Poe- 
try. Social Scientist, 4, 13-16.

Luo, J. (2018). Study on the Negroes' Cultural Otherness in I, Too, Sing America. In 2018 International Conference on Arts, Linguistics, Literature and Humanities (ICALLH) (28-31). UK: Francis Academic Press.

Luo, L.-G. (2005). On the Humor of Langston Hughes. Foreign Literature Studies, 4, 25-31.

Rampersad, A. (1986). A Review of "The Life of Langston Hughes, Vol. I, 1902-1941: I, Too, Sing America”. Kikus Review, 12, 1005.

Rampersad, A. (2001). The Collected Works of Langston Hughes: The Poems: 1931-1940 (Vol. 1, p. 46 ). Columbia: University of Missouri Press.

Singh, A. (1976). "When the Negro Was in Vogue". The Harlem Renaissance and Black America. In A. Singh (Ed.), The Novels of the Harlem Renaissance: Twelve Black Writers, 1923-1933 (pp. 1-39). Pennsylvania: The Pennsylvania State University Press.

Turner, D. T. (1980). The Harlem Renaissance: One Facet of an Unturned Kaleidoscope. In L. J. Budd, E. H. Cady, \& C. L. Anderson (Eds.), Toward a New American Literary History: Essays in Honor of Arlin Turner (pp. 195-210). Durham: Duke University Press.

Zheng, Y. (2008). A Post-Colonialist Interpretation of Langston Hughes's Poetry. Journal of Sichuan College of Education, 12, 59-65.

Zhu, Y.-T. (1991). Essentials of British and American Culture (9th ed., pp. 425-426). Beijing: Foreign Language Teaching and Research Press. 